Review Article

\title{
New Insights into the Process of Placentation and the Role of Oxidative Uterine Microenvironment
}

\author{
Sara Mendes $\mathbb{D}^{1,2}$ Filipa Timóteo-Ferreira $\mathbb{D}^{1,2}$ Henrique Almeida $\mathbb{D}^{1,2,3}$ \\ and Elisabete Silva ${ }^{10}{ }^{1,2}$ \\ ${ }^{1}$ Ageing and Stress Group, IBMC (Instituto de Biologia Molecular e Celular), I3S (Instituto de Investigação e Inovação em Saúde), \\ Universidade do Porto, Rua Alfredo Allen 208, 4200-135 Porto, Portugal \\ ${ }^{2}$ Unidade de Biologia Experimental, Departamento de Biomedicina, Faculdade de Medicina, Universidade do Porto, \\ Alameda Professor Hernâni Monteiro, 4200-319 Porto, Portugal \\ ${ }^{3}$ Ginecologia-Obstetrícia, Hospital-CUF Porto, Estrada da Circunvalação 14341, 4100180 Porto, Portugal
}

Correspondence should be addressed to Elisabete Silva; elisabete.silva@i3s.up.pt

Received 22 February 2019; Accepted 28 May 2019; Published 25 June 2019

Academic Editor: José L. Quiles

Copyright (C) 2019 Sara Mendes et al. This is an open access article distributed under the Creative Commons Attribution License, which permits unrestricted use, distribution, and reproduction in any medium, provided the original work is properly cited.

For a successful pregnancy to occur, a predecidualized receptive endometrium must be invaded by placental differentiated cells (extravillous trophoblast cells (EVTs)) and, at the same time, continue decidualization. EVT invasion is aimed at anchoring the placenta to the maternal uterus and ensuring local blood supply increase necessary to provide normal placental and foetal development. The first is achieved by migrating through the maternal endometrium and deeper into the myometrium, while the second by transforming uterine spiral arteries into large vessels. This process is a tightly regulated battle comprising interests of both the mother and the foetus. Invading EVTs are required to perform a scope of functions: move, adhere, proliferate, differentiate, interact, and digest the extracellular matrix (ECM); tolerate hypoxia; transform the maternal spiral arteries; and die by apoptosis. All these functions are modulated by their surrounding microenvironment: oxygen, soluble factors (e.g., cytokines, growth factors, and hormones), ECM proteins, and reactive oxygen species. A deeper comprehension of oxidative uterine microenvironment contribution to trophoblast function will be addressed in this review.

\section{Introduction}

Successful pregnancy depends on sequential and discrete events that include fertilization, implantation, decidualization, placentation, and birth. Placentation is the process of formation and development of the placenta and the associated modifications in maternal tissue. Its continued interaction character, involving two distinct genomes, suggests the presence of a fine-tuned regulation. In human placenta development, three structural regions are considered: the foetal placenta, with separated foetal and maternal blood, where physiological exchange of nutrients and waste products occurs; the basal plate, which borders the maternal surface and is crossed by maternal vessels; and the placental bed formed by maternal uterine tissue, comprising the modified endometrium (decidua) and is traversed by 100-150 mater- nal spiral arteries that supply nutrients and oxygen $\left(\mathrm{O}_{2}\right)$ to the placenta and the foetus [1]

For a healthy pregnancy to proceed, a good anchoring of placental features and the transformation of maternal spiral arteries (SA) into flaccid capacitation vessels, that will ensure adequate blood supply to the foetus, are necessary. In normal pregnancy, such changes require important extravillous trophoblast cell (EVT) movement from the placental villi across the decidua and deep into the adjacent myometrium. In addition, appropriate invasion of maternal SA and their resulting remodelling underlies functional circulatory change establishment [2]. In contrast, deficient EVT invasion has been associated with insufficient SA remodelling, altered uteroplacental hemodynamics, overall placenta bed dysfunction, and the establishment of serious pregnancy complications [3]. In fact, an early defective development of the placental bed, and 
consequent altered placentation, appears to contribute to late pregnancy complications such as preeclampsia, placental abruption, and intrauterine growth restriction (IUGR) $[1,2]$.

EVT invasion regulation and the molecular mechanisms underlying SA remodelling are the result of a complex network involving soluble factors and different cell types residing in the maternal placental bed. Emerging work indicates that an abnormal placentation is consequent to aberrant uterine microenvironment, already present before or at the time of blastocyst implantation [4-7]. This review will address uterine regulators of EVT dynamics with a special focus on reactive oxygen species (ROS) physiological and pathophysiological roles.

\section{Pre(decidualization)}

In many species, uterine changes aiming to create a suitable microenvironment for embryo implantation and development occur only after implantation. In humans, early changes may be recognized after ovulation and are designated predecidualization [8]. In the uterine stroma adjacent to SA, and in response to rising progesterone levels, fibroblast-like mesenchymal cells differentiate into an epithelioid structure. In addition, they accumulate cytoplasmic glycogen and lipids and secrete new products as components of extracellular matrix (ECM), protease inhibitors, cytokines, hormones, and other peptides. If implantation takes place, they will provide nutrition to the developing conceptus [9].

Progesterone-dependent differentiation of stroma cells is crucial for epithelium receptiveness and trophoblastendometrium interactions. In fact, trophoblast spheroid attachment and growth in a coculture of endometrial epithelial cells and primary stromal cells were increased when stromal cells had been collected during the window of implantation time, not before [10].

Predecidualization also plays an important role in uterine natural killer (uNK) cell influx. In humans, they are recruited during predecidualization, and their increase peaks during the first trimester and diminishes thereafter, due to apoptosis. When compared with circulating NK cells, uNK cells have distinct features and functions. They are less cytotoxic and produce signalling molecules such as cytokines (e.g., tumour necrosis factor alpha (TNF- $\alpha$ ) and interleukin- (IL) 10 and $1 \beta$ ), growth factors (e.g., tissue growth factor beta (TGF- $\beta$ ) and placental growth factor (PlGF)), angiogenic factors (e.g., vascular endothelial growth factor (VEGF)), and matrix metalloproteinases (MMPs) [11]. Moreover, they contribute to decidual angiogenesis regulation and SA remodelling and control EVT invasion [12].

\section{Implantation and Early Placentation}

Upon fertilization, the ovum travels in the fallopian tube where following several mitotic divisions, it reaches the morula stage (a compact mass of 12-16 cells). Continuing to divide, while receiving nutrients from the uterine environment, it attains approximately 100 cells that surround a fluid-filled cavity, where conceptus-derived secretions concentrate, characterizing the blastocyst stage [13]. During this stage, asymmetric cell divisions give rise to two distinct populations: the outer blastocyst encircling trophoblast cells, which will originate both the placenta and the extraembryonic membranes, and the totipotent inner cell mass, which will develop into the embryo [14]. Between the $5^{\text {th }}$ and the $6^{\text {th }}$ day post fertilization, the blastocyst contacts with the uterine wall (apposition), attaches to the epithelium, and invades the receptive decidua to implant $[15,16]$ (Figure 1).

After implantation, trophoblasts that face directly the maternal tissue differentiate and fuse to form the syncytiotrophoblast, whereas those remaining behind, untouched by maternal tissue, do not fuse and are denominated cytotrophoblasts [17, 18] (Figure 1). They act as a rapidly dividing stem cell pool that feeds and fuses with the multinucleated syncytiotrophoblast and promotes its continuous growth. Soon, it will surround most of the blastocyst and, with an invasive phenotype, will penetrate deep into the uterine cavity lining. Within the syncytium, fluid-filled spaces coalesce and rearrange into lacunae, which are the primitive intervillous spaces in the placenta, where the maternal blood will circulate $[19,20]$.

While invasion evolves, columns of the syncytiotrophoblast masses establish a network around the lacunae to form trabeculae, very important for the remaining development of the villous tree. Subsequently, cytotrophoblast cells proliferate and invade through the trabeculae, until they reach their tips and contact with the decidua. Following their lateral spreading from the tips, they form a coating between the syncytiotrophoblast mantle and the maternal endometrium [21]. Therefore, at this stage, the blastocyst exhibits three different layers of trophoblastic covering: (1) the primary/early chorionic plate, which faces the embryo; (2) the lacunar system and trabeculae, which develops into the intervillous space and villous tree, respectively; and (3) the cytotrophoblastic shell or primitive basal plate, which contacts directly with the endometrium [21].

The cells from the cytotrophoblastic shell possess a distinct phenotype, as they exhibit a round outline structure and large amounts of glycogen. Those localized at the tips of villi differentiate into EVTs, leave the shell, and migrate across the endometrium, initiating the process of EVT invasion [22]. A batch of EVTs is responsible for SA remodelling: they disrupt the vascular smooth cell layer and replace the endothelium, converting muscular wall arteries into wide bore low-resistance vessels ensuring a local increase in blood supply, necessary to fulfil placenta requirements [23]. At the same time, these cells accumulate and plug the lumen of the transformed SA, obstructing blood cell circulation. Nevertheless, there is a plasma leak which results in a physiological gradient of $\mathrm{O}_{2}$ between the mother and the foetus, with extreme importance for organogenesis [2]. In a phenomenon named deep placentation, EVTs further invade the decidua and reach as far as the inner third of the myometrium.

\section{Modulators of EVT Function and Associated Signalling Pathways}

Extravillous trophoblasts are not isolated elements as they are surrounded by decidual cells, vascular features, ECM 


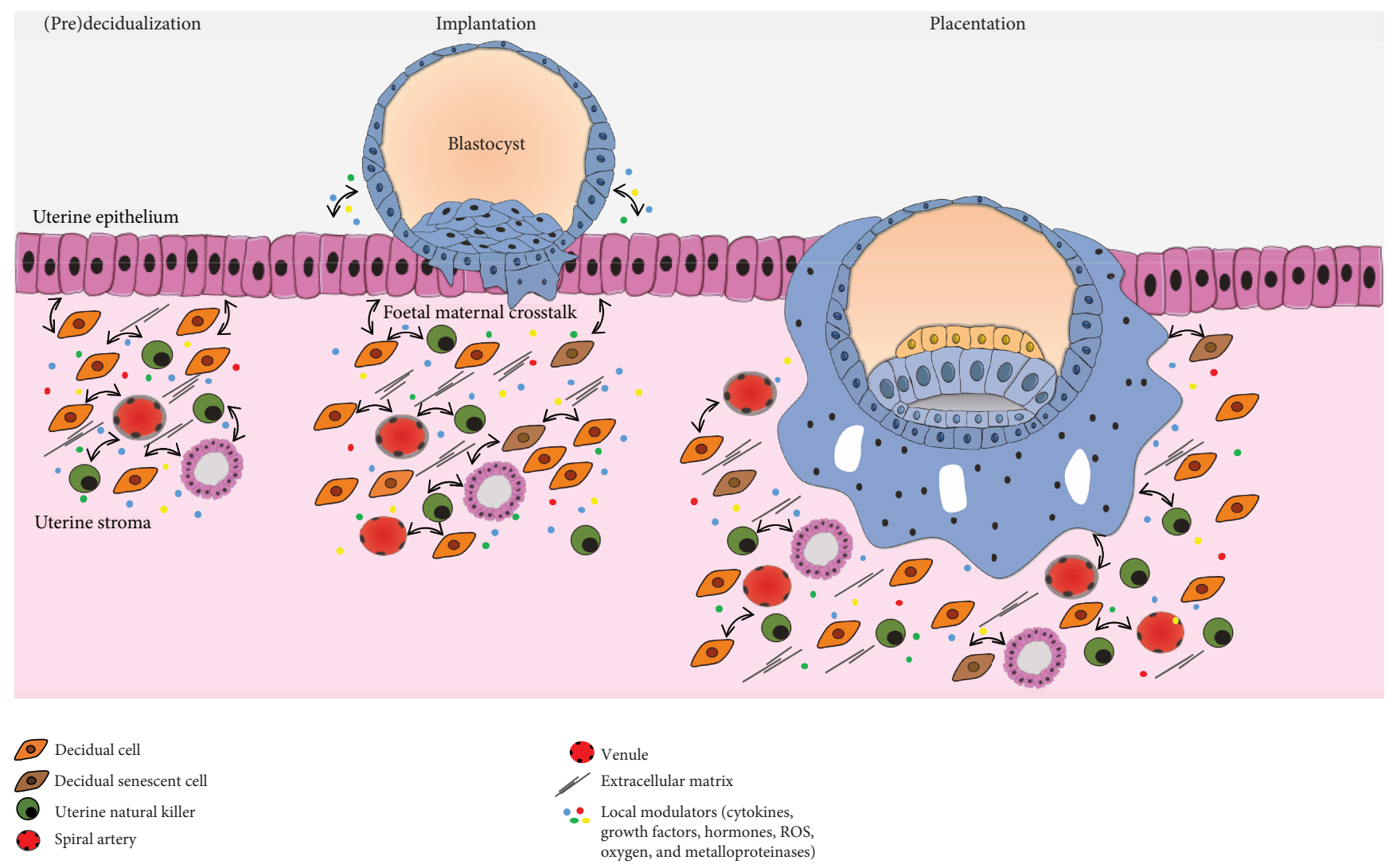

Figure 1: Human placenta development. Blastocyst implantation is mediated by the crosstalk between the blastocyst and the receiving endometrium. Early differentiated syncytiotrophoblast, displaying an invasive phenotype, allows the blastocyst to implant inside the endometrial stroma. Cytokines, growth factors, hormones, oxygen, extracellular matrix, and ROS all modulate trophoblast cell invasion of maternal decidua and myometrium and their capacity to transform spiral arteries. Many growth factors and cytokines, such as EGF, TGF- $\beta$, and TNF- $\alpha$, secreted by the decidua and UNK cells act in a paracrine manner to regulate trophoblast function. These factors may also be secreted by the trophoblast cells and act in an autocrine manner to promote invasion.

proteins, uNK cells, and soluble factors, which together constitute the uterine microenvironment (Figure 2). This microenvironment must be suitable for an effective implantation that is the pillar for a successful pregnancy.

4.1. Oxygen. Low $\mathrm{O}_{2}$ levels are essential for correct placental development. In fact, during the first trimester of pregnancy, when SA are plugged by EVTs, there is an abrupt decrease in $\mathrm{O}_{2}$ concentration from the decidua to the developing placenta $[24,25]$. This gradient is essential for cell column basement-residing cytotrophoblast cells to proliferate, reach the tips of the columns, and differentiate into invading extravillous trophoblasts. It thus appears that dividing cytotrophoblasts are pushed forward, towards maternal tissue and higher $\mathrm{O}_{2}$ levels, where they lose proliferative capacity, acquire an invasive phenotype, and start invading the maternal tissue [26]. Low $\mathrm{O}_{2}$ levels also induce the expression and stability of transcription factors, such as hypoxia-inducible factor-1 (HIF-1), which promotes expression of genes that encode proteins involved in cell metabolism, essential for trophoblast proliferation and differentiation [27].

4.2. Adhesion Molecules and Receptors. The transition from proliferating cytotrophoblast cells to invasive EVTs is also dependent on specific cell receptors and cell adhesion molecule (CAM) alterations. It starts with trophoblast cell detachment from the basal membrane and culminates with de novo adhesion to uterine ECM, enabling EVTs to further migrate and invade the myometrium and SA. A variety of molecules with a role in adhesion, motility, and migratory capacity are present in the EVTs and include integrins, selectins, cadherins, kisspeptins, and ephrins $[28,29]$. Integrins are the major family of CAM with a key importance in the abovementioned processes. Their expression differs among trophoblast populations and modulates the binding to the ECM. In addition, locally produced cytokines can influence CAM expression, particularly TGF- $\beta$ [30]. EVT integrins bind to ECM proteins and other decidual molecules and activate cellular pathways controlling trophoblast functions [31].

4.3. Extracellular Matrix. The decidual ECM is a 3dimensional tissue structure where trophoblast lineages are embedded. This matrix is composed of a variety of proteins including collagen, fibronectin, laminin, vitronectin, trophin, and tastin [32]. ECM modulate EVT functions and, at the same time, EVTs degrade and induce ECM remodelling to enable migration [33-35]. 


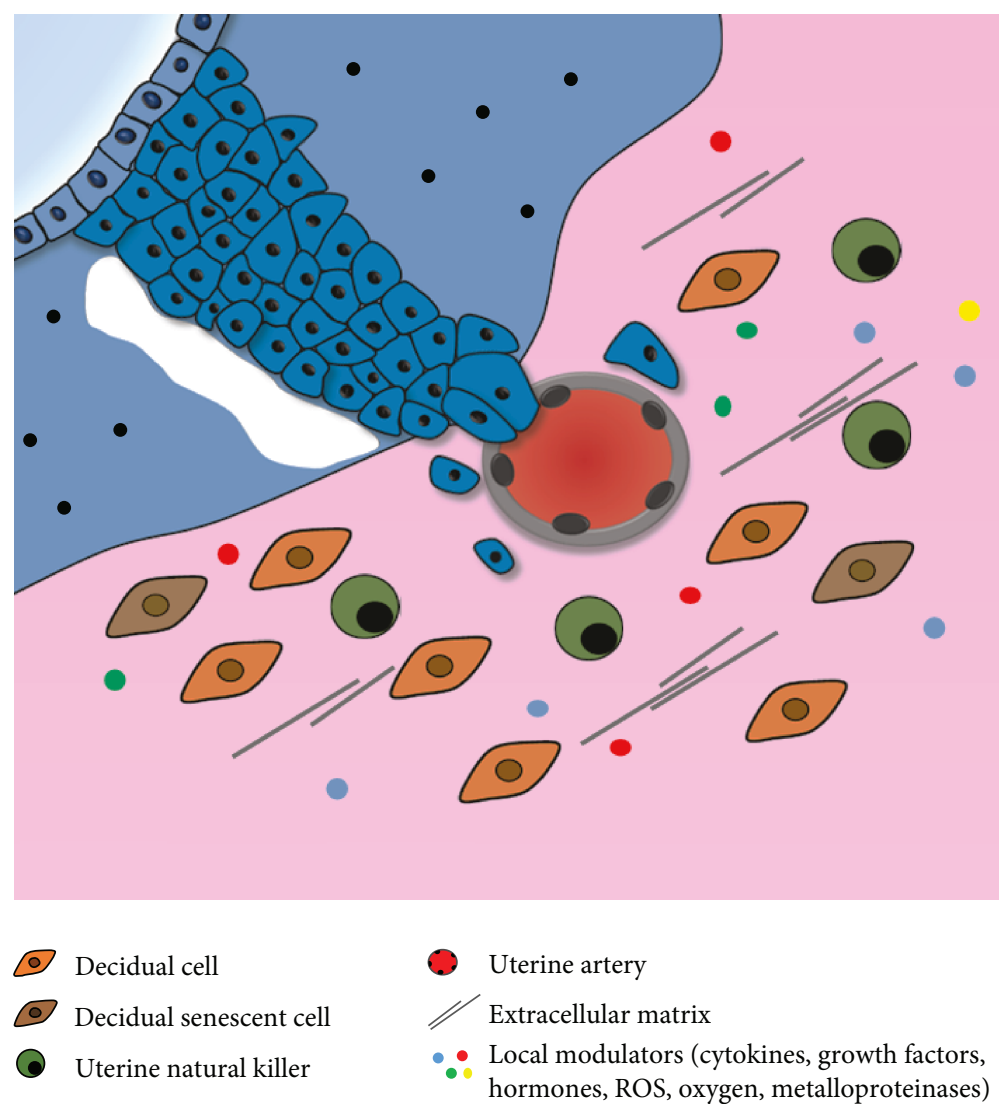

FIGURE 2: Extravillous trophoblast invasion and spiral artery remodelling. Within the syncytium, lacunae (the primitive intervillous space) are formed and proliferative cytotrophoblast cells emanate until they contact the endometrium (anchoring villi). At the tips of the villi, cytotrophoblasts differentiate into invasive trophoblast cells that will leave the villi and migrate through the stroma until they reach maternal spiral arteries or the deep myometrium. Interstitial extravillous trophoblasts that reach spiral arteries disrupt the vascular smooth muscle cell layer and replace it by fibrinoid material, while endovascular trophoblasts destroy their lumen and occupy their endometrium, converting them into low-resistance vessels.

TABLE 1: Classification of matrix metalloproteinases.

\begin{tabular}{|c|c|c|c|c|c|}
\hline \multicolumn{3}{|c|}{ MMP classification } & \multirow{2}{*}{$\begin{array}{c}\text { Enzyme substrates } \\
\text { Collagen types I, II, III, VII, and X }\end{array}$} & \multirow{2}{*}{$\begin{array}{l}\text { Cell type/tissue secretion } \\
\text { EVTs, decidua, and uNK }\end{array}$} & \multirow{2}{*}{$\frac{\text { References }}{[39-42]}$} \\
\hline \multirow{3}{*}{ Collagenases } & Collagenase- 1 & MMP-1 & & & \\
\hline & Collagenase-2 & MMP-8 & Collagen types I and III & EVTs, decidua & {$[39,43,44]$} \\
\hline & Collagenase- 3 & MMP-13 & Collagen type I & EVTs, decidua & {$[39,44-46]$} \\
\hline \multirow[t]{2}{*}{ Gelatinases } & Gelatinase A & MMP-2 & $\begin{array}{l}\text { Collagen types I, III, IV, V, VII, and X; } \\
\text { gelatin; fibronectin; and elastin }\end{array}$ & EVTs, decidua, and uNK & {$[39,42,44,47-52]$} \\
\hline & Gelatinase B & MMP-9 & Collagen types I, III, IV, and V and gelatin & EVTs, decidua, and uNK & {$[39,42,44,47-50,52]$} \\
\hline \multirow{6}{*}{ Stromelysins } & Stromelysin-1 & MMP-3 & $\begin{array}{l}\text { Collagen types III, IV, IX, and X; gelatin; } \\
\text { laminin; fibronectin; and elastin }\end{array}$ & EVTs, decidua & {$[39,44,50,53]$} \\
\hline & Stromelysin-2 & MMP-10 & $\begin{array}{l}\text { Collagen types II, IV, and V; } \\
\text { fibronectin; and gelatin }\end{array}$ & EVTs, decidua, and uNK & {$[39,44,50,54]$} \\
\hline & Stromelysin-3 & MMP-11 & Collagen type IV & EVTs, decidua, and uNK & {$[39,44]$} \\
\hline & Matrilysin & MMP-7 & Fibronectin and gelatin & EVTs, decidua, and uNK & {$[39,41,42,44,45]$} \\
\hline & Matrilysin-2 & MMP-26 & Fibronectin and gelatin & EVTs, decidua & {$[39,55,56]$} \\
\hline & Metalloelastase & MMP-12 & Elastin and fibronectin & EVTs, decidua, and uNK & {$[39,44,57,58]$} \\
\hline
\end{tabular}


ECM proteins are degraded by proteases, cathepsins, and MMPs [36]. MMPs belong to the family of zinc-dependent endopeptidases, with diverse members that degrade distinct units of the ECM (Table 1) [37, 38].

Regulation of MMP expression can be done at different levels: transcriptional (e.g., cytokines and growth factors), during secretion, by extracellular activation (e.g., plasminactivated MMP-3), by inhibition (e.g., tissue inhibitors of metalloproteinases (TIMPs)), or by degradation [59, 60]. TIMPs are a family of extracellular proteins (TIMP-1, TIMP-2, TIMP-3, and TIMP-4), which act as specific protease inhibitors, binding to the catalytic MMP domain and counteracting MMP activity [61].

Cell-matrix or cell-cell contact mediates both MMPs and TIMPs production [62]. To invade, EVTs must bind to ECM components, degrade them, and subsequently move through the tissue matrix. Cell surface adhesion molecules are essential for cell adhesion and constitutively express proteinases for ECM degradation [63]. Both EVT adhesion molecules and MMP secretion are dependent on ECM composition [36] and their phenotypic features. EVTs show an early predominant expression of MMP-2 that changes to MMP-9 later on during trophoblast invasion, to cope with decidual ECM alterations [64-67]. Overall, decidual cells, when in contact with EVTs, also express MMPs assisting in ECM degradation and further enhancing trophoblast invasion [67], but they also antagonize MMP activity by producing TIMPs and consequently blocking trophoblast invasion [68].

Decidual cells balance MMPs and TIMP secretion, control EVT migration, and prevent an exacerbate invasion [69] in a tight regulation and following a strict balance [70]. Thus, in order to achieve a correct placentation, uterine microarchitecture remodelling is necessary and requires a fine-tuned regulatory process operated by multiple players, of which only a limited number is currently known.

4.4. Soluble Factors-Cytokines and Growth Factors. Both timing and extension of EVT invasion are partly regulated by a plethora of paracrine and autocrine factors expressed by different cells comprising the decidua and EVTs themselves. Moreover, expression of these factors shows a considerable structural overlap, with several mediators being expressed by the decidua, uNK, and trophoblast cells [71]. In a decidualized endometrium, the cytokine/chemokine secretion is unique and, with the exception of leukaemia inhibitory factor (LIF), the expression of these soluble factors is increased when compared with nondecidualized stromal cells (Table 2).

Due to such alteration, it is conceivable that the decidual secretome has a role in controlling trophoblast invasion [73]. In a simplified way, soluble mediators can be divided in two groups: pro- and anti-invasive. Proinvasive paracrine factors, which have been shown to increase in vitro cell migration, invasion, and adhesion, comprise IL-1, IL-6, IL8, IL-15, LIF, insulin-like growth factor-binding protein 1 (IGFBP-1), epidermal growth factor (EGF), interferon gamma-induced protein 10 (IP-10), RANTES (regulated on activation, normal $\mathrm{T}$ cell expressed and secreted), and chemokines CX3CL1 and CCL14. Anti-invasive factors
TABLe 2: Molecules secreted in response to decidualization.

\begin{tabular}{lc}
\hline Soluble factors & Reference \\
\hline EGF $\uparrow$ & {$[72]$} \\
$\mathrm{IL}-1 \beta \uparrow$ & {$[73]$} \\
$\mathrm{IL}-6 \uparrow$ & {$[73]$} \\
$\mathrm{IL}-8 \uparrow$ & {$[73]$} \\
$\mathrm{IL}-10 \uparrow$ & {$[74]$} \\
$\mathrm{IL}-11 \uparrow$ & {$[75,76]$} \\
$\mathrm{IL}-15 \uparrow$ & {$[76]$} \\
$\mathrm{IGFBP}-1 \uparrow$ & {$[75,76]$} \\
$\mathrm{IP}-10 \uparrow$ & {$[73]$} \\
$\mathrm{LIF} \downarrow$ & {$[77]$} \\
RANTES $\uparrow$ & {$[73]$} \\
TGF- $\beta \uparrow$ & {$[72]$} \\
TNF- $\alpha \uparrow$ & {$[72]$} \\
VEGF $\uparrow$ & {$[72]$} \\
\hline
\end{tabular}

include IL-10, IL-12, TNF- $\alpha$, TGF- $\beta$, interferon gamma (IFN- $\gamma$ ), chemokine CXCL12, VEGF, and endocrine glandderived VEGF (EG-VEGF) (Table 3).

Apart from the decidua, other tissues are producers of trophoblast regulators. Leptin, produced in the adipose tissue and in trophoblasts, can enhance EVT invasion capacity by an effective increase in MMP-14 expression [134-136]. In a placental bed, paracrine factors bind to the EVT cognate receptors and trigger signalling cascades that regulate gene expression and enzymatic activity, which induce a shift in MMPs, ILs, and growth factor secretion. This variation further regulates, in a feedforward fashion, a plethora of soluble factors that also control invasion.

4.5. Signalling Pathways. Several signalling pathways are responsible for controlling migration and invasion of EVTs including mitogen-activated protein kinase (MAPK), phosphoinositide 3-kinase (PI3K)/protein kinase B (Akt), Janus kinase (JAK)/signal transducer and activator of transcription proteins (STATs), wingless (Wnt), and focal adhesion kinase (FAK) pathways. However, endometrium-derived soluble factors predominantly activate MAPK, JAK/STAT, and TGF- $\beta$-mediated signalling pathways.

One of the most important pathways of MAPK signalling is extracellular signal-regulated kinase (ERK) 1/2. It participates in essential functions as cell proliferation, differentiation, and survival [137]. This pathway can be activated by mitogens, phorbol esters, growth factors, and ROS [137, 138]. In pregnancy, ERK1/2 is important for placental development [139], trophoblast differentiation, and decidual invasion $[138,140]$. Endothelin and prostaglandins activate ERK1/2 and promote EVT migration, while inhibition of this pathway reduces it [140]. The p38 MAPK pathway is also an important MAPK signalling pathway; it is activated by cytokines [141], among other agents, and is necessary in the control of apoptosis, inflammation, cell cycle regulation, senescence, and oncogenesis $[141,142]$. In particular, the p38 $\alpha$ isoform plays a vital role in placental embryonic 
TABLE 3: Soluble factors secretion and its effect on invasion.

\begin{tabular}{|c|c|c|c|c|}
\hline & Soluble factor & Secreted by & Effects on trophoblast invasion & References \\
\hline \multirow{13}{*}{ Proinvasive } & CCL14 & & Increase migration by promoting CAM expression & {$[64,78]$} \\
\hline & CX3CL1 & Decidua & $\begin{array}{c}\text { alterations ( } \alpha \text {-catenin and integrin } \beta 5 \text { ); increase invasion } \\
\text { by increasing MMP-12 expression }\end{array}$ & [78] \\
\hline & EGF & $\begin{array}{l}\text { Decidua and } \\
\text { mesenchymal villi }\end{array}$ & $\begin{array}{c}\text { Increase invasion by increasing MMP-9 and TIMP-1 } \\
\text { expression }\end{array}$ & {$[65,79-82]$} \\
\hline & HGF & $\begin{array}{l}\text { Decidua, placental } \\
\text { stromal cells, and uNK }\end{array}$ & $\begin{array}{l}\text { Increase invasion by upregulating of H2.0-like homeobox } \\
\text { gene }\end{array}$ & {$[83,84]$} \\
\hline & IGFBP-1 & Decidua & Increase invasion by increasing gelatinolytic activity & {$[31,85-87]$} \\
\hline & IL- $1 \beta$ & $\begin{array}{l}\text { Cytotrophoblasts, } \\
\text { decidua, macrophages, } \\
\text { and uNK }\end{array}$ & $\begin{array}{l}\text { Increase invasion by increasing MMP-2, MMP-9, and } \\
\text { urokinase plasminogen activator expression }\end{array}$ & {$[78,88-95]$} \\
\hline & IL-6 & $\begin{array}{l}\text { Cytotrophoblasts and } \\
\text { uNK }\end{array}$ & $\begin{array}{c}\text { Increase invasion by increasing MMP-2 and MMP-9 } \\
\text { expression }\end{array}$ & {$[91,96-101]$} \\
\hline & IL-8 & $\begin{array}{l}\text { Cytotrophoblasts, } \\
\text { decidua, macrophages, } \\
\text { and uNK }\end{array}$ & $\begin{array}{l}\text { Increase invasion by increasing MMP-2, MMP-9, uPA, } \\
\text { and plasminogen activator inhibitor (PAI) type } 1 \text { and } 2 \\
\text { expression }\end{array}$ & {$[102,103]$} \\
\hline & IL-15 & Decidual cells & Increase invasion by increasing MMP-1 expression & {$[76,104,105]$} \\
\hline & IP-10 & $\begin{array}{l}\text { Endometrial stromal } \\
\text { cells, uterine glandular } \\
\text { cells, and uNK }\end{array}$ & $\begin{array}{l}\text { Increase migration by increasing integrin expression } \\
\qquad(\alpha 5 \text { and } \beta 3)\end{array}$ & {$[106-108]$} \\
\hline & LIF & $\begin{array}{l}\text { Decidual stromal cells } \\
\text { and uNK }\end{array}$ & $\begin{array}{l}\text { Increase adhesion through changes in integrin expression; } \\
\text { increase invasion by decreasing TIMP-1 expression }\end{array}$ & {$[109-115]$} \\
\hline & RANTES & Uterine stromal cells & $\begin{array}{c}\text { Increase adhesion and migration by increasing cytolytic } \\
\text { activity and integrin expression }(\beta 1)\end{array}$ & {$[116-118]$} \\
\hline & IL-11 & $\begin{array}{l}\text { Cytotrophoblasts, uNK, } \\
\text { and decidua }\end{array}$ & $\begin{array}{l}\text { Involvement in EVT function less understood; inhibiting } \\
\text { invasion in HTR-8/SVneo and increasing in JEG-3 }\end{array}$ & {$[119-121]$} \\
\hline \multirow{7}{*}{ Anti-invasive } & CXCL14 & Decidual stromal cells & Decrease invasion by gelatinase activity suppression & {$[64]$} \\
\hline & IL-10 & Macrophages and uNK & $\begin{array}{c}\text { Decrease invasion by downregulating MMP-2 and MMP-9 } \\
\text { expression }\end{array}$ & [122] \\
\hline & INF- $\gamma$ & $\begin{array}{l}\text { Cytotrophoblasts, } \\
\text { decidua, and uNK }\end{array}$ & $\begin{array}{c}\text { Decrease invasion by decreasing insulin-like growth factor } \\
\text { receptor-II }\end{array}$ & {$[123-127]$} \\
\hline & Kisspeptin-10 & $\begin{array}{l}\text { Cytotrophoblasts and } \\
\text { decidua }\end{array}$ & $\begin{array}{l}\text { Decrease invasion by binding to g protein-coupled } \\
\text { receptor kisspeptin-1 receptor increasing } \mathrm{Ca}^{2+} \\
\text { intracellular levels }\end{array}$ & {$[123-127]$} \\
\hline & TGF- $\beta$ & $\begin{array}{l}\text { Cytotrophoblasts, } \\
\text { decidua, and uNK }\end{array}$ & $\begin{array}{l}\text { Decrease invasion by increasing of TIMP-1 and TIMP-2 } \\
\text { and plasminogen activator inhibitor type } 1 \text { and } 2 \\
\text { expression; increases adhesion by upregulating the } \\
\text { expression of CAM (ezrin and e-cadherin) }\end{array}$ & $\begin{array}{c}{[62,79,85,123-125,} \\
128-130]\end{array}$ \\
\hline & TNF- $\alpha$ & $\begin{array}{l}\text { Cytotrophoblasts, } \\
\text { decidua, macrophages, } \\
\text { and uNK }\end{array}$ & $\begin{array}{c}\text { Decrease invasion by upregulation plasminogen activator } \\
\text { inhibitor type } 1 \text { expression }\end{array}$ & {$[123,125,130-132]$} \\
\hline & VEGF & $\begin{array}{l}\text { Decidua, macrophages, } \\
\text { and uNK }\end{array}$ & $\begin{array}{c}\text { Decrease invasion by inhibiting urokinase plasminogen } \\
\text { activator expression }\end{array}$ & [133] \\
\hline
\end{tabular}

development and placental angiogenesis [143]. ERK1/2 inhibition in parallel with p38 MAPK decreases trophoblast differentiation [138]. Activation of the MAPK pathway in combination with the PI3K/Akt pathway promotes EVT (HTR-8/SVneo immortalized cell line) invasion and migration via MMP enhancement [144].

JAK/STAT3 signalling is indispensable for regulation of EVT proliferation and invasion capacity in response to cytokines and growth factors $[145,146]$. Again, an interdependence between MAPK and JAK-STAT signalling pathways was found to be involved in EGF-mediated HTR-8/SVneo cell invasion [146].

TGF- $\beta$ signals through Smad-dependent (canonical) and Smad-independent (ERK, JNK, p38, and Rho GTPases) (noncanonical) pathways. Recent studies with JEG trophoblast cells demonstrate that activation of Smad3 promotes cell invasion by upregulation of MMP2 and MMP9 [147]. These findings contrast with previous reports where TGF- $\beta$ decreased EVT invasion in HTR-8/SVneo cells, by inducing Snail-mediated downregulation of vascular endothelial- 
cadherin [147]. TGF- $\beta$ plays a role in multiple signalling networks in the cell, and depending on the second messengers involved, divergent responses can be attained.

ROS are important secondary messengers and play a role in the modulation of protein kinase activity. When a redox imbalance occurs, ROS can impair the EVT signalling network. Modification of essential amino acid residues by ROS, which consequently alter the protein structure and its function, is one of the plausible mechanisms of ROS actions [148].

\section{Oxidative Stress and Placentation}

5.1. Reactive Oxygen Species, Oxidative Stress, and Placentation. The ROS family comprises free radicals (i.e., species with at least one unpaired electron) and nonradical oxidants (i.e., oxidants with their electronic ground state complete). These species reactivity, half-lives, and diffusion capacities are variable. Hydroxyl radical $(\mathrm{OH})$ is the most unstable and upon formation reacts rapidly with biomolecules in the vicinity [149]. In contrast, hydrogen peroxide $\left(\mathrm{H}_{2} \mathrm{O}_{2}\right)$ is capable of crossing cell membranes and exerts its effects beyond the cell limits [150, 151].

Under physiological conditions, superoxide anion $\left(\mathrm{O}_{2}^{--}\right)$ is the most frequently generated radical. Its main source is the inner mitochondrial membrane during the respiratory chain, particularly the complexes I and III, by inevitable leakage of electrons to $\mathrm{O}_{2}[152,153] . \mathrm{O}_{2}{ }^{-\prime}$ can also be formed following electron leakage in a shorter electron transport chain at the endoplasmic reticulum (ER) and during the membrane-bound nicotinamide adenine dinucleotide phosphate oxidase (NOX) activity, which transfers one electron from NADPH to $\mathrm{O}_{2}$ [154].

To cope with the continued ROS production, cells have developed antioxidant mechanisms that prevent their accumulation and deleterious actions. Antioxidants, enzymatic or nonenzymatic, can mitigate ROS effects by delaying oxidation or preventing it from happening. In cells, key enzymatic antioxidants are superoxide dismutase (SOD), catalase (CAT), and glutathione peroxidase (GPx) [155], whereas important nonenzymatic antioxidants comprise vitamins $\mathrm{C}$ (ascorbic acid) and E (tocopherol), zinc and selenium, glutathione, plant polyphenols, and carotenoids (carotene and $\beta$ carotene) [156]. Other molecules with moderate antioxidant properties may also be relevant because of their abundance, as is serum albumin [157].

ROS are normal products of cell metabolism with physiological roles in the organisms. They regulate signalling pathways through changes in the activity of structural proteins, transcription factors, membrane receptors, ion channels, and protein kinases/phosphatases [158] However, when ROS levels rise, and antioxidant defences cannot neutralize them, the redox homeostasis is disrupted, and a new state referred as oxidative stress (OS) arises. OS leads to an impairment of redox signalling and causes molecular damage to biomolecules $[159,160]$. OS condition is graded; while minor or moderated changes provoke an adaptive response and homeostasis restauration, higher ones result in violent perturbations that lead to pathological insults, damage beyond repair, and even cell death [159] (Figure 3).

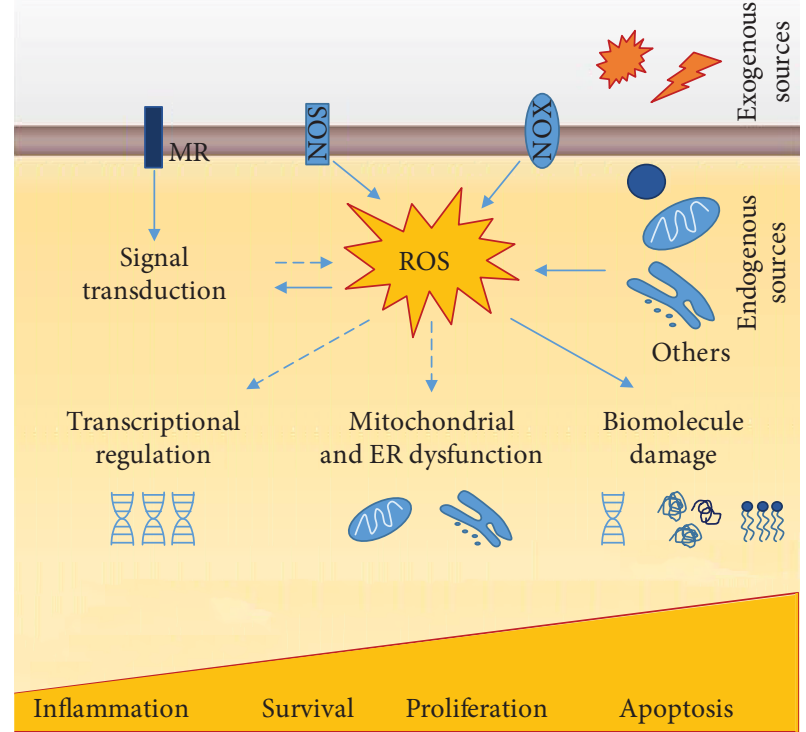

FIgURE 3: ROS sources and downstream cellular effects. Endogenous sources of ROS include mitochondrial metabolic reactions, NADPH oxidase activity, and microsomal cytochrome P450 detoxification pathways; exogenous sources comprehend ultraviolet radiation, X-rays and gamma-rays, ultrasounds, pesticides, herbicides, and xenobiotics. ROS are normal products of cell metabolism with physiological roles in the organisms. They regulate signalling pathways through changes in the activity of structural proteins, transcription factors, membrane receptors, ion channels, and protein kinases/phosphatases. However, when ROS levels rise, and antioxidant defence cannot neutralize them, the redox homeostasis is disrupted, and a new state referred to as oxidative stress (OS) arises. OS leads to impairment of redox signalling and induces damage to biomolecules. OS has a graded response with minor or moderated changes provoking an adaptive response and homeostasis restauration and violent perturbations leading to pathological insults, damage beyond repair, and even cell death. MR: membrane receptor; NOS: nitric oxide synthase; NOX: NADPH oxidase. Filled arrows indicate a direct action, while dashed arrows indicate indirect or simplified mechanisms.

5.1.1. ROS in the Endometrium Cycle. ROS are believed to be implicated in the regulation of the endometrial cycle (Figure 4) [161]. NOX-derived $\mathrm{O}_{2}^{--}$has been shown to activate the nuclear factor kappa-light-chain-enhancer of activated $B$ cells $(\mathrm{NF}-\kappa \mathrm{B})$ and regulate angiogenesis $[162,163]$, thus resulting in a determinant role in the endometrial cycle. Variations in SOD, GPx, and lipid peroxides in response to oestrogen and progesterone levels have also been reported $[164,165]$. In a late secretory phase, steroid hormone fall reduces SOD activity and, consequently, increases ROS effects $[166,167]$. ROS-mediated activation of NF- $\kappa$ B signalling cascade promotes prostaglandin secretion, vasoconstriction, and, ultimately, the endometrial shedding [168-171], at the end of the secretory phase. The exacerbated uterine ROS level and NF- $\kappa \mathrm{B}$ activation may result in signalling pathway disruption and in a broad spectrum of uterine-related infertility disorders, as endometriosis [172]. In recurrent pregnancy loss (RPL), increased activity of antioxidant enzymes and decreased markers of OS in endometrial secretions before implantation associated positively with a successful 


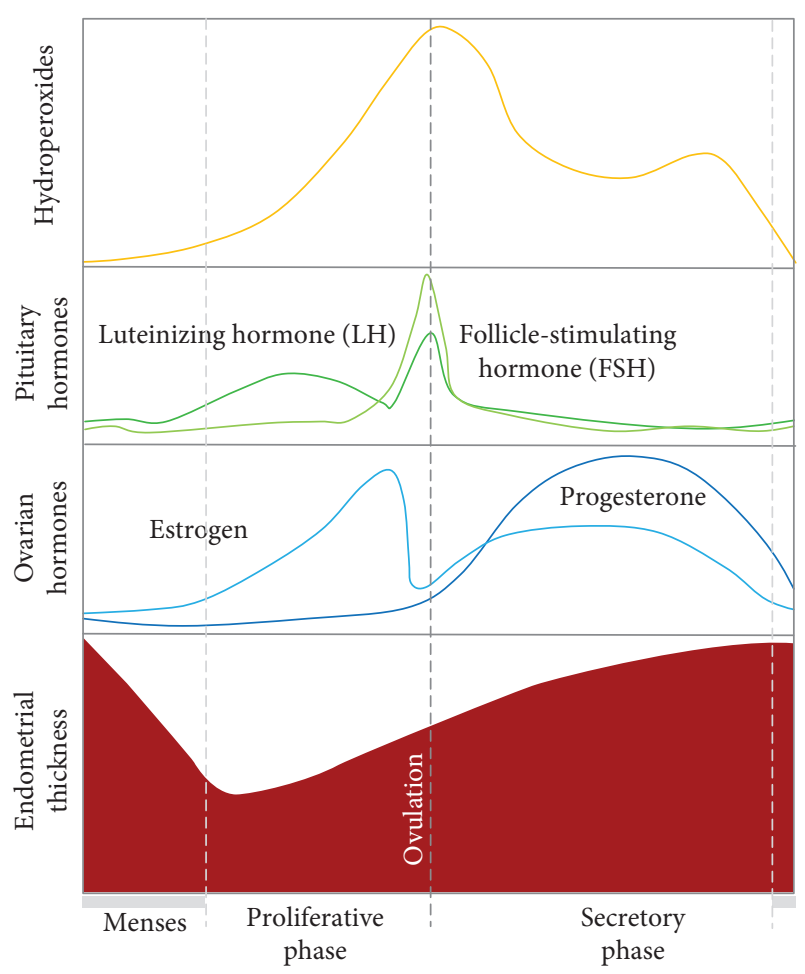

FIgURE 4: Diagrammatic representation of the different phases of the menstrual cycle, oxidative stress (OS) changes, and fluctuations in ovarian and pituitary hormones. Plasmatic OS marker (hydroperoxides) maximum levels are seen near ovarian and pituitary hormone peaks [161].

IVF outcome [173]. Moreover, endometrial alterations in progesterone-induced SGK1 (a serine-threonine protein kinase homologous to AKT) were also related to RPL due to impairment in OS defences [174].

5.1.2. ROS and Decidualization. Recent findings suggest that decidual stromal cells evolved from ancestor stromal cell fibroblasts, whose phenotype acquisition is modulated by redox signalling, ER stress, and cellular senescence [175]. In this context, resveratrol, a molecule with antioxidant and anti-inflammatory properties, inhibits decidualization in mice by repression of decidualization markers and abrogation of cellular senescence [176], whereas decidual cell ER sensitive to stressful conditions results in a decrement of decidual functioning $[177,178]$ and viability [179]. In short, during decidualization, redox-sensitive transcription factors and kinases are activated, making plausible the intervention of ROS and their regulators in this process [180-182] and extending it into placentation. In pregnancy, progesterone stimulates uterine stromal decidualization and decidual SOD expression [183, 184]. In addition, GPx3 is highly expressed in mice decidua, favouring its involvement in uterine transformation and implantation, a point further supported by the reduced pregnancy rates upon GPx3 inhibition [165].

5.1.3. ROS and Regulation of Trophoblast Function. EVTs are also adversely regulated by OS because of their interference with fundamental cellular pathways, reduction of MMP expression, upregulation of proinflammatory cytokine secretion, and induction of mitochondrial dysfunction [185-192]. These consequences disrupt EVT crosstalk within the uterine microenvironment and impair fundamental biological processes as differentiation, proliferation, migration, and vascular remodelling (Table 4). The use of specific antioxidant molecules may have beneficial effects on EVT functions $[186,188,189]$.

5.1.4. The Ageing Uterus. In the aged uterus, indirect evidence supports the occurrence of cellular senescence, which is thought to affect decidual transformation [195] and promote preterm births [196, 197]. In addition, reproductively aged mice show age-related increase in uterine NOX and protein carbonylation content, contributing to abnormal decidualization and reduced fertility. NOX inhibition, but not enhanced $\mathrm{H}_{2} \mathrm{O}_{2}$ conversion using a SOD mimetic, restores local redox balance, repairs maternal-foetal interactions, and increases fertility [6]. In line with these results are the recent findings of Banerjee and coworkers reporting that low $\mathrm{H}_{2} \mathrm{O}_{2}$ levels increase EVT invasion, while high levels induce apoptosis [191, 194]. Interestingly, an age-related decrease in adrenal synthesis of dehydroepiandrosterone (DHEA) is believed to grant increased antioxidant capacity to decidualized cells and improve endometrial receptivity [198-200].

On a wider view, either by disturbing uterine decidua or embryo-derived cell functioning, important aspects of modern life style such as obesity, increased maternal age, alcohol consumption, and exposure to substances may act as endocrine disruptors and affect implantation and placentation through OS induction $[6,7,185,190,193,201]$.

Therefore, it is now recognized that, at the time of implantation, OS-related alterations in uterine microenvironment lead to a relevant disturbance at the foetus/maternal interface that impairs trophoblast invasion and spiral artery remodelling and stand at the root of major pregnancyrelated complications of vascular origin, such as preeclampsia and IUGR.

5.2. AGEs, RAGEs, ROS, and Placentation. Glycation is a nonenzymatic reaction (not to be confused with the enzymatic reaction glycosylation), between reducing sugars (e.g., glucose, fructose, or galactose) and amino groups of proteins, lipids, or nucleic acids. Advanced glycation end-products (AGEs) are the result of a series of glycation reactions [202]. The formation of AGEs was first described by Maillard in the beginning of the $20^{\text {th }}$ century; however, the chemical reactions were only described later in the setting of food research [202]. Briefly, in the classic Maillard reaction, electrophilic carbonyl groups of reducing sugars interact with free amino acid residues (especially arginine or lysine) and form unstable Schiff bases that reverse when glucose levels drop. Further rearrangements result in the formation of the more stable, but still reversible, "Amadori products," which can react with peptides or protein amino acids, this time irreversibly, leading to the formation of AGEs [203, 204]. The Maillard reaction is not the unique pathway for AGE 
TABLE 4: ROS-mediated regulation of trophoblast function.

\begin{tabular}{|c|c|c|c|}
\hline Agent & Molecular effects & EVT functions & Reference \\
\hline Decanoic acid & $\begin{array}{c}\text { Disrupts mitochondrial function } \\
\uparrow \text { ROS generation } \\
\downarrow \text { Akt and ERK1/2 pathways }\end{array}$ & $\begin{array}{c}\downarrow \text { proliferation } \\
\downarrow \text { invasion }\end{array}$ & {$[185]$} \\
\hline Trichloroethylene & $\begin{array}{l}\text { Disrupts mitochondrial function } \\
\uparrow \text { ROS generation } \\
\uparrow \text { proinflammatory cytokine production }\end{array}$ & - & {$[190]$} \\
\hline Benzo(a)pyren-7,8-dihydrodiol-9,10-epoxide & $\begin{array}{c}\text { Disrupts mitochondrial function } \\
\uparrow \text { ROS generation } \\
\downarrow \text { SOD activity } \\
\text { Induces apoptosis }\end{array}$ & $\downarrow$ invasion & [193] \\
\hline Higher $\mathrm{H}_{2} \mathrm{O}_{2}$ concentrations & Induces apoptosis & $\downarrow$ invasion & {$[194]$} \\
\hline Lower $\mathrm{H}_{2} \mathrm{O}_{2}$ concentrations & $\begin{array}{l}\uparrow \text { STAT } 1 \text { and } 3 \text { pathways } \\
\uparrow \text { MMP-9/TIMP- } 1 \text { ratio }\end{array}$ & $\uparrow$ invasion & {$[191]$} \\
\hline Selenium (under hypoxic conditions) & $\downarrow$ mitochondrial stress & $\underset{\uparrow \text { migration }}{\uparrow \text { proliferation }}$ & [186] \\
\hline Edaravone (under hypoxic conditions) & $\downarrow$ ROS production & $\begin{array}{c}\uparrow \text { proliferation } \\
\uparrow \text { migration } \\
\uparrow \text { invasion }\end{array}$ & {$[187]$} \\
\hline Flavonoids (under hypoxia/reoxygenation) & $\downarrow$ ROS production & - & [189] \\
\hline
\end{tabular}

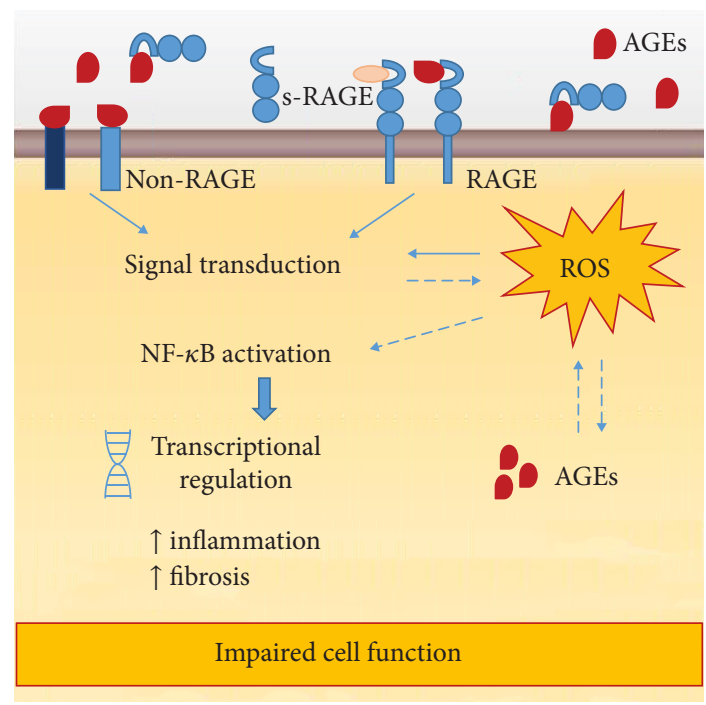

FIGURE 5: Advanced glycation end-product (AGE) pathological effects. Most of AGE effects are dependent on the interaction AGE/RAGE (receptor of AGE) and the activation of transduction pathways. However, AGEs can bind non-RAGE proteins, and interestingly, RAGE can be activated by other ligands. AGE interactions with membrane receptors trigger various ROSmediated signalling pathways that converge on NF- $\kappa \mathrm{B}$ activation and transcriptional regulation of genes, which impairs cell function. The proteolytic cleavage of extracellular RAGE originates circulating peptides referred as soluble RAGE (sRAGE). It is believed that sRAGEs act as decoy receptors, which scavenge circulating AGEs, preventing them from binding functional membrane RAGE and inducing cellular responses.

formation because other reactions involving the formation of carbonyl-containing reactive compounds end up as AGEs [205, 206]. As such, it is not surprising that AGEs are a quite complex, heterogeneous group of compounds, formed either exogenously (e.g., dietary AGEs) and endogenously, by different mechanisms and precursors. ROS, $\mathrm{O}_{2}$, and transition metals are catalysers of AGE synthesis [207] and AGE interactions with membrane receptors that trigger various ROS-mediated signalling pathways, such as ERK1/2-MAPK, PI3K-Akt, and p38-SAPK-JNK [208, 209] (Figure 5).

Very little is known about AGE physiological role, and few researches have addressed this issue. Cerami hypothesized that AGEs were protein residues that acted as signals, targeting them to degradation, and that age-related AGE accumulation resulted from loss of efficiency of the removal system [210]. Other authors have explored methylglyoxal, an AGE precursor, as an antimicrobial and anticarcinogenic agent [211].

A handful of papers have also explored AGEs as preconditioners, preparing cells to exacerbated OS, and thus contributing to a future improvement in antioxidant/inflammation response [212-215]. Up to date, nothing is known about a putative antioxidant or antifibrotic effect of dietary AGEs on obstetric-related disorders, although there is a possibility that is worth exploring.

An increase in AGE levels accompanies the ageing process itself and is also a significant contributor and a major risk factor to the development of several ageassociated disorders. Higher levels of circulating AGEs or AGE receptor (RAGE) activation have been found in diabetes, hypertension [216], systemic lupus erythematosus [217], rheumatoid arthritis [218], Alzheimer disease [219], and neoplasia [220, 221]. Interestingly, elevated circulation AGEs have also been found in pregnancy-associated complications such as severe preeclampsia [222] and gestational diabetes mellitus (GDM) [223] where it has been positively correlated with proinflammatory markers [224]. In animal models, 
treatment with soluble RAGE, RAGE inhibitors, and antioxidant molecules ameliorates placental complications [225].

5.2.1. AGEs, ROS, and Regulation of Trophoblast Function. In vitro experiments with trophoblasts isolated from first trimester chorionic villi showed that AGE administration increased apoptosis, proinflammatory cytokine production, and monocyte migration. Activation of the NF- $\kappa$ B pathway was crucial to the observed AGE-mediated cell responses, since an inhibitor of this pathway displayed beneficial effects [226]. In accordance, AGEs were found to be upstream molecules that trigger ROS production, activate soluble fms-like tyrosine kinase-1 (sFlt-1), VEGF, and PlGF [227], increase cytokine production in immortalized trophoblast cell lines isolated from first trimester villi (HTR-8/SVneo and Sw.71 cells), and enhance monocyte migration [228, 229]. This inflammatory environment conditions placenta development. Anti-RAGE immunoglobulin or antioxidant treatment also proved effective in reverting AGE-mediated cell effects [227]. Recently, work from Antoniotti et al. showed that uterine AGE levels found in obese women impair uterine transformation and trophoblast function [7].

Overall, data obtained from both in vivo and in vitro experiments demonstrated that AGEs alter trophoblast function through ROS increase and activation of the NF- $\kappa$ B pathway [227, 229-231], supporting the view that an age-related imbalance in uterine oxidative microenvironment, present even before pregnancy, conditions implantation.

\section{Concluding Remarks and Future Perspectives}

Placenta central function is to supply an adequate amount of blood to properly nourish the foetus. To achieve this purpose, a receptive endometrium is permeated by extravillous trophoblast cells that invade it as deep as the muscular layer. This invasion anchors the placenta to the maternal uterus and guarantees local blood supply through a surprising structural and functional change in maternal spiral arteries: by way of the replacement of their walls by embryo-derived cells, their resistance properties are converted into capacitance features. Such a process requires coordination and cooperation between maternal and foetal tissues.

Similar to key roles played by ROS in processes as oocyte maturation and fertilization, ROS involvement continues in decidualization, implantation, modulation of trophoblast proliferation and differentiation, and embryo development.

A balance between oxidant and antioxidant molecules is vital for a successful ending. The placenta is a growing organ that must evade the adverse effects of homeostasis loss and adapt to reinstall homeostasis. However, when local redox status is significantly disturbed, and severe OS is established, molecular and cellular damage ensues. In the decidualized uterus, those events alter protein function and structure and signalling pathways, disrupt ECM and cytokine production, and hamper the microenvironment at the maternalfoetal interface.

More researchers are convinced that alterations in the foetal-maternal microenvironment before pregnancy, whether by ROS or AGEs, are the culprits and the etiopathogenic roots of pregnancy-related complications of vascular origin. Clearly, we have much to learn, by unravelling ROSmediated molecular mechanisms dysregulated at the uterus.

\section{Conflicts of Interest}

The authors declare that there is no conflict of interest regarding the publication of this paper.

\section{References}

[1] F. Lyall, "The human placental bed revisited," Placenta, vol. 23 , no. 8-9, pp. 555-562, 2002.

[2] F. Lyall, "Priming and remodelling of human placental bed spiral arteries during pregnancy-a review," Placenta, vol. 26, pp. S31-S36, 2005.

[3] C. W. G. Redman and I. L. Sargent, "Placental stress and preeclampsia: a revised view," Placenta, vol. 30, pp. 38-42, 2009.

[4] E. R. Norwitz, "Defective implantation and placentation: laying the blueprint for pregnancy complications," Reproductive Biomedicine Online, vol. 13, no. 4, pp. 591-599, 2006.

[5] S. Lu, H. Peng, H. Zhang et al., "Excessive intrauterine fluid cause aberrant implantation and pregnancy outcome in mice," PLoS One, vol. 8, no. 10, article e78446, 2013.

[6] E. Silva, A. I. Soares, F. Costa, J. P. Castro, L. Matos, and H. Almeida, "Antioxidant supplementation modulates agerelated placental bed morphology and reproductive outcome in mice," Biology of Reproduction, vol. 93, no. 3, p. 56, 2015 .

[7] G. S. Antoniotti, M. Coughlan, L. A. Salamonsen, and J. Evans, "Obesity associated advanced glycation end products within the human uterine cavity adversely impact endometrial function and embryo implantation competence," Human Reproduction, vol. 33, no. 4, pp. 654-665, 2018.

[8] B. Gellersen and J. J. Brosens, "Cyclic decidualization of the human endometrium in reproductive health and failure," Endocrine Reviews, vol. 35, no. 6, pp. 851-905, 2014.

[9] K. Vinketova, M. Mourdjeva, and T. Oreshkova, "Human decidual stromal cells as a component of the implantation niche and a modulator of maternal immunity," Journal of Pregnancy, vol. 2016, Article ID 8689436, 17 pages, 2016.

[10] A. Evron, S. Goldman, and E. Shalev, "Effect of primary human endometrial stromal cells on epithelial cell receptivity and protein expression is dependent on menstrual cycle stage," Human Reproduction, vol. 26, no. 1, pp. 176-190, 2010.

[11] L. M. Gaynor and F. Colucci, "Uterine natural killer cells: functional distinctions and influence on pregnancy in humans and mice," Frontiers in Immunology, vol. 8, p. 467, 2017.

[12] J. C. Cheng, H. M. Chang, and P. C. K. Leung, “TGF- $\beta 1$ inhibits human trophoblast cell invasion by upregulating connective tissue growth factor expression," Endocrinology, vol. 158, no. 10, pp. 3620-3628, 2017.

[13] J. L. Maitre, "Mechanics of blastocyst morphogenesis," Biology of the Cell, vol. 109, no. 9, pp. 323-338, 2017.

[14] J. Aplin, "Maternal influences on placental development," Seminars in Cell \& Developmental Biology, vol. 11, no. 2, pp. 115-125, 2000.

[15] H. Matsumoto, "Molecular and cellular events during blastocyst implantation in the receptive uterus: clues from mouse 
models," The Journal of Reproduction and Development, vol. 63, no. 5, pp. 445-454, 2017.

[16] B. C. Paria, Y. M. Huet-Hudson, and S. K. Dey, "Blastocyst's state of activity determines the "Window" of implantation in the receptive mouse uterus," Proceedings of the National Academy of Sciences of the United States of America, vol. 90, no. 21, pp. 10159-10162, 1993.

[17] P. Bischof and I. Irminger-Finger, "The human cytotrophoblastic cell, a mononuclear chameleon," The International Journal of Biochemistry \& Cell Biology, vol. 37, no. 1, pp. 116, 2005.

[18] S. Handwerger, "New insights into the regulation of human cytotrophoblast cell differentiation," Molecular and Cellular Endocrinology, vol. 323, no. 1, pp. 94-104, 2010.

[19] A. J. G. Pötgens, U. Schmitz, P. Bose, A. Versmold, P. Kaufmann, and H. G. Frank, "Mechanisms of syncytial fusion: a review,” Placenta, vol. 23, pp. S107-S113, 2002.

[20] J. D. Boyd and W. J. Hamilton, The Human Placenta, Cambridge [England]: Heffer, 1970.

[21] K. Benirschke and P. Kaufman, Pathology of the Human Placenta, Springer, 2000.

[22] D. N. Modi, G. Godbole, P. Suman, and S. K. Gupta, "Endometrial biology during trophoblast invasion," Frontiers in Bioscience (Scholar Edition), vol. 4, pp. 1151-1171, 2012.

[23] E. W. Dempsey, "The development of capillaries in the villi of early human placentas," The American Journal of Anatomy, vol. 134, no. 2, pp. 221-237, 1972.

[24] E. Jauniaux, A. L. Watson, J. Hempstock, Y. P. Bao, J. N. Skepper, and G. J. Burton, "Onset of maternal arterial blood flow and placental oxidative stress. A possible factor in human early pregnancy failure," The American Journal of Pathology, vol. 157, no. 6, pp. 2111-2122, 2000.

[25] I. Caniggia, J. Winter, S. J. Lye, and M. Post, "Oxygen and placental development during the first trimester: implications for the pathophysiology of pre-eclampsia," Placenta, vol. 21, pp. S25-S30, 2000.

[26] P. Kaufmann, S. Black, and B. Huppertz, "Endovascular trophoblast invasion: implications for the pathogenesis of intrauterine growth retardation and preeclampsia," Biology of Reproduction, vol. 69, no. 1, pp. 1-7, 2003.

[27] I. Caniggia, H. Mostachfi, J. Winter et al., "Hypoxia-inducible factor-1 mediates the biological effects of oxygen on human trophoblast differentiation through TGF $\beta_{3}$," The Journal of Clinical Investigation, vol. 105, no. 5, pp. 577$587,2000$.

[28] L. K. Harris, C. J. P. Jones, and J. D. Aplin, "Adhesion molecules in human trophoblast - a review. II. Extravillous trophoblast," Placenta, vol. 30, no. 4, pp. 299-304, 2009.

[29] J. D. Aplin, C. J. P. Jones, and L. K. Harris, "Adhesion molecules in human trophoblast - a review. I. Villous trophoblast," Placenta, vol. 30, no. 4, pp. 293-298, 2009.

[30] D. Male, J. Rahman, A. Linke, W. Zhao, and W. Hickey, “An interferon-inducible molecule on brain endothelium which controls lymphocyte adhesion mediated by integrins," Immunology, vol. 84, no. 3, pp. 453-460, 1995.

[31] L. M. Gleeson, C. Chakraborty, T. McKinnon, and P. K. Lala, "Insulin-like growth factor-binding protein 1 stimulates human trophoblast migration by signaling through $\alpha 5 \beta 1$ integrin via mitogen-activated protein kinase pathway," The Journal of Clinical Endocrinology and Metabolism, vol. 86, no. 6, pp. 2484-2493, 2001.
[32] J. S. Krussel, P. Bielfeld, M. L. Polan, and C. Simon, "Regulation of embryonic implantation," European Journal of Obstetrics, Gynecology, and Reproductive Biology, vol. 110, pp. S2-S9, 2003.

[33] P. Xu, Y. Wang, Y. Piao et al., "Effects of matrix proteins on the expression of matrix metalloproteinase-2, -9 , and -14 and tissue inhibitors of metalloproteinases in human cytotrophoblast cells during the first trimester," Biology of Reproduction, vol. 65, no. 1, pp. 240-246, 2001.

[34] E. Staun-Ram and E. Shalev, "Human trophoblast function during the implantation process," Reproductive Biology and Endocrinology, vol. 3, no. 1, p. 56, 2005.

[35] P. Lu, K. Takai, V. M. Weaver, and Z. Werb, "Extracellular matrix degradation and remodeling in development and disease," Cold Spring Harbor Perspectives in Biology, vol. 3, no. 12, 2011.

[36] P. Bischof, A. Meisser, and A. Campana, "Biochemistry and molecular biology of trophoblast invasion," Annals of the New York Academy of Sciences, vol. 943, no. 1, pp. 157-162, 2001.

[37] M. Cohen, A. Meisser, and P. Bischof, "Metalloproteinases and human placental invasiveness," Placenta, vol. 27, no. 8, pp. 783-793, 2006.

[38] M. Seiki, "Membrane-type matrix metalloproteinases," APMIS, vol. 107, no. 1-6, pp. 137-143, 1999.

[39] J. Anacker, S. E. Segerer, C. Hagemann et al., "Human decidua and invasive trophoblasts are rich sources of nearly all human matrix metalloproteinases," Molecular Human Reproduction, vol. 17, no. 10, pp. 637-652, 2011.

[40] C. L. Deng, S. T. Ling, X. Q. Liu, Y. J. Zhao, and Y. F. Lv, "Decreased expression of matrix metalloproteinase-1 in the maternal umbilical serum, trophoblasts and decidua leads to preeclampsia," Experimental and Therapeutic Medicine, vol. 9, no. 3, pp. 992-998, 2015.

[41] W. Li, N. Cui, M. Q. Mazzuca, K. M. Mata, and R. A. Khalil, "Increased vascular and uteroplacental matrix metalloproteinase- 1 and -7 levels and collagen type I deposition in hypertension in pregnancy: role of TNF- $\alpha$," American Journal of Physiology. Heart and Circulatory Physiology, vol. 313, no. 3, pp. H491-h507, 2017.

[42] Z. Ren, N. Cui, M. Zhu, and R. A. Khalil, "Placental growth factor reverses decreased vascular and uteroplacental MMP2 and MMP-9 and increased MMP-1 and MMP-7 and collagen types I and IV in hypertensive pregnancy," American Journal of Physiology. Heart and Circulatory Physiology, vol. 315, no. 1, pp. H33-H47, 2018.

[43] L. Rahkonen, E. M. Rutanen, M. Nuutila, S. Sainio, T. Sorsa, and J. Paavonen, "Matrix metalloproteinase- 8 in cervical fluid in early and mid pregnancy: relation to spontaneous preterm delivery," Prenatal Diagnosis, vol. 30, no. 11, pp. 1079-1085, 2010.

[44] T. T.-T. N. Nguyen, O. Shynlova, and S. J. Lye, "Matrix metalloproteinase expression in the rat myometrium during pregnancy, term labor, and postpartum," Biology of Reproduction, vol. 95, no. 1, p. 24, 2016.

[45] K. Wolf, P. Sandner, A. Kurtz, and W. Moll, "Messenger ribonucleic acid levels of collagenase (MMP-13) and matrilysin (MMP-7) in virgin, pregnant, and postpartum uterus and cervix of rat," Endocrinology, vol. 137, no. 12, pp. 5429-5434, 1996.

[46] S. J. Fortunato, B. LaFleur, and R. Menon, "Collagenase-3 (MMP-13) in fetal membranes and amniotic fluid during 
pregnancy," American Journal of Reproductive Immunology, vol. 49, no. 2, pp. 120-125, 2003.

[47] R. Nissi, A. Talvensaari-Mattila, V. Kotila, M. Niinimäki, I. Järvelä, and T. Turpeenniemi-Hujanen, "Circulating matrix metalloproteinase MMP-9 and MMP-2/TIMP-2 complex are associated with spontaneous early pregnancy failure," Reproductive Biology and Endocrinology, vol. 11, no. 1, p. 2, 2013.

[48] J. Chen and R. A. Khalil, "Matrix metalloproteinases in normal pregnancy and preeclampsia," Progress in Molecular Biology and Translational Science, vol. 148, pp. 87-165, 2017.

[49] S. C. Riley, R. Leask, T. Chard, N. C. Wathen, A. A. Calder, and D. C. Howe, "Secretion of matrix metalloproteinase-2, matrix metalloproteinase- 9 and tissue inhibitor of metalloproteinases into the intrauterine compartments during early pregnancy," Molecular Human Reproduction, vol. 5, no. 4, pp. 376-381, 1999.

[50] A. Lombardi, S. Makieva, S. F. Rinaldi, F. Arcuri, F. Petraglia, and J. E. Norman, "Expression of matrix metalloproteinases in the mouse uterus and human myometrium during pregnancy, labor, and preterm labor," Reproductive Sciences, vol. 25, no. 6, pp. 938-949, 2017.

[51] C. Guo and L. Piacentini, "Type I collagen-induced MMP-2 activation coincides with up-regulation of membrane type 1-matrix metalloproteinase and TIMP-2 in cardiac fibroblasts," The Journal of Biological Chemistry, vol. 278, no. 47, pp. 46699-46708, 2003.

[52] H. F. Bigg, A. D. Rowan, M. D. Barker, and T. E. Cawston, "Activity of matrix metalloproteinase-9 against native collagen types I and III," The FEBS Journal, vol. 274, no. 5, pp. 1246-1255, 2007.

[53] M. O'Brien, D. O'Shaughnessy, E. Ahamide, J. J. Morrison, and T. J. Smith, "Differential expression of the metalloproteinase MMP3 and the alpha5 integrin subunit in human myometrium at labour," Molecular Human Reproduction, vol. 13, no. 9, pp. 655-661, 2007.

[54] N. Lagzouli, B. Sayer, S. Ashton, J. Cartwright, and G. Whitley, "Trophoblasts stimulate the release of MMP10 by endothelial cells," Placenta, vol. 45, p. 77, 2016.

[55] Q. Li, H. Wang, Y. Zhao, H. Lin, Q. A. Sang, and C. Zhu, "Identification and specific expression of matrix metalloproteinase-26 in rhesus monkey endometrium during early pregnancy," Molecular Human Reproduction, vol. 8, no. 10, pp. 934-940, 2002.

[56] K. Isaka, H. Nishi, H. Nakai et al., "Matrix metalloproteinase26 is expressed in human endometrium but not in endometrial carcinoma," Cancer, vol. 97, no. 1, pp. 79-89, 2003.

[57] U. Hiden, E. Glitzner, M. Ivanisevic et al., "MT1-MMP expression in first-trimester placental tissue is upregulated in type 1 diabetes as a result of elevated insulin and tumor necrosis factor- $\alpha$ levels," Diabetes, vol. 57, no. 1, pp. 150 157, 2007.

[58] L. K. Harris, S. D. Smith, R. J. Keogh et al., "Trophoblastand vascular smooth muscle cell-derived MMP-12 mediates elastolysis during uterine spiral artery remodeling," The American Journal of Pathology, vol. 177, no. 4, pp. 21032115, 2010.

[59] A. H. Baker, D. R. Edwards, and G. Murphy, "Metalloproteinase inhibitors: biological actions and therapeutic opportunities," Journal of Cell Science, vol. 115, no. 19, pp. 3719-3727, 2002.
[60] C. Yan and D. D. Boyd, "Regulation of matrix metalloproteinase gene expression," Journal of Cellular Physiology, vol. 211, no. 1, pp. 19-26, 2007.

[61] G. Murphy, "Tissue inhibitors of metalloproteinases," Genome Biology, vol. 12, no. 11, p. 233, 2011.

[62] P. Bischoff, A. Meisser, and A. Campana, "Paracrine and autocrine regulators of trophoblast invasion-a review," Placenta, vol. 21, pp. S55-S60, 2000.

[63] B. Huppertz, S. Kertschanska, A. Y. Demir, H. G. Frank, and P. Kaufmann, "Immunohistochemistry of matrix metalloproteinases (MMP), their substrates, and their inhibitors (TIMP) during trophoblast invasion in the human placenta," Cell and Tissue Research, vol. 291, no. 1, pp. 133148, 1998.

[64] N. J. Hannan and L. A. Salamonsen, "CX3CL1 and CCL14 regulate extracellular matrix and adhesion molecules in the trophoblast: potential roles in human embryo implantation," Biology of Reproduction, vol. 79, no. 1, pp. 58-65, 2008.

[65] E. Staun-Ram, S. Goldman, D. Gabarin, and E. Shalev, "Expression and importance of matrix metalloproteinase 2 and 9 (MMP-2 and -9) in human trophoblast invasion," Reproductive Biology and Endocrinology, vol. 2, no. 1, p. 59, 2004.

[66] K. Isaka, S. Usuda, H. Ito et al., "Expression and activity of matrix metalloproteinase 2 and 9 in human trophoblasts," Placenta, vol. 24, no. 1, pp. 53-64, 2003.

[67] M. Iwahashi, Y. Muragaki, A. Ooshima, M. Yamoto, and R. Nakano, "Alterations in distribution and composition of the extracellular matrix during decidualization of the human endometrium," Journal of Reproduction and Fertility, vol. 108, no. 1, pp. 147-155, 1996.

[68] S. Espino Y Sosa, A. Flores-Pliego, A. Espejel-Nuñez et al., "New insights into the role of matrix metalloproteinases in preeclampsia," International Journal of Molecular Sciences, vol. 18, no. 7, p. 1448, 2017.

[69] E. Staun-Ram, S. Goldman, and E. Shalev, "p53 mediates epidermal growth factor (EGF) induction of MMP-2 transcription and trophoblast invasion," Placenta, vol. 30, no. 12, pp. 1029-1036, 2009.

[70] Y. Seval, G. Akkoyunlu, R. Demir, and M. Asar, "Distribution patterns of matrix metalloproteinase (MMP)-2 and -9 and their inhibitors (TIMP-1 and TIMP-2) in the human decidua during early pregnancy," Acta Histochemica, vol. 106, no. 5, pp. 353-362, 2004.

[71] M. Knofler and J. Pollheimer, "IFPA award in Placentology lecture: molecular regulation of human trophoblast invasion," Placenta, vol. 33, pp. S55-S62, 2012.

[72] R. M. Popovici, L.-C. Kao, and L. C. Giudice, "Discovery of new inducible genes in in vitro decidualized human endometrial stromal cells using microarray technology," Endocrinology, vol. 141, no. 9, pp. 3510-3515, 2000.

[73] S. Sharma, G. Godbole, and D. Modi, "Decidual control of trophoblast invasion," American Journal of Reproductive Immunology, vol. 75, no. 3, pp. 341-350, 2016.

[74] P. Viganò, E. Somigliana, S. Mangioni, M. Vignali, M. Vignali, and A. M. Di Blasio, "Expression of interleukin10 and Its receptor is up-regulated in early pregnant versus cycling human endometrium," The Journal of Clinical Endocrinology \& Metabolism, vol. 87, no. 12, pp. 57305736, 2002. 
[75] N. Karpovich, P. Klemmt, J. H. Hwang et al., "The production of interleukin-11 and decidualization are compromised in endometrial stromal cells derived from patients with infertility," The Journal of Clinical Endocrinology \& Metabolism, vol. 90, no. 3, pp. 1607-1612, 2005.

[76] G. Godbole and D. Modi, "Regulation of decidualization, interleukin-11 and interleukin-15 by homeobox a 10 in endometrial stromal cells," Journal of Reproductive Immunology, vol. 85, no. 2, pp. 130-139, 2010.

[77] L. L. Shuya, E. M. Menkhorst, J. Yap, P. Li, N. Lane, and E. Dimitriadis, "Leukemia inhibitory factor enhances endometrial stromal cell decidualization in humans and mice," PLoS One, vol. 6, no. 9, article e25288, 2011.

[78] J. Hanna, D. Goldman-Wohl, Y. Hamani et al., "Decidual NK cells regulate key developmental processes at the human fetal-maternal interface," Nature Medicine, vol. 12, no. 9, pp. 1065-1074, 2006.

[79] J. J. Lysiak, I. H. Connelly, N. K. S. Khoo, W. StetlerStevenson, and P. K. Lala, "Role of transforming growth factor- $\alpha$ (TGF $\alpha$ ) and epidermal growth factor (EGF) on proliferation and invasion by first trimester human trophoblast," Placenta, vol. 15, pp. 455-467, 1994.

[80] G. E. Hofmann, R. T. Scott Jr., P. A. Bergh, and L. Deligdisch, "Immunohistochemical localization of epidermal growth factor in human endometrium, decidua, and placenta," The Journal of Clinical Endocrinology \& Metabolism, vol. 73, no. 4, pp. 882-887, 1991.

[81] E. Y. Anteby, C. Greenfield, S. Natanson-Yaron et al., "Vascular endothelial growth factor, epidermal growth factor and fibroblast growth factor-4 and -10 stimulate trophoblast plasminogen activator system and metalloproteinase-9," Molecular Human Reproduction, vol. 10, no. 4, pp. 229235, 2004.

[82] Q. Qiu, M. Yang, B. K. Tsang, and A. Gruslin, "EGF-induced trophoblast secretion of MMP-9 and TIMP-1 involves activation of both PI3K and MAPK signalling pathways," Reproduction, vol. 128, no. 3, pp. 355-363, 2004.

[83] J. E. Cartwright, D. P. Holden, and G. S. J. Whitley, "Hepatocyte growth factor regulates human trophoblast motility and invasion: a role for nitric oxide," British Journal of Pharmacology, vol. 128, no. 1, pp. 181-189, 1999.

[84] S. Saito, S. Sakakura, M. Enomoto, M. Ichijo, K. Matsumoto, and T. Nakamura, "Hepatocyte growth factor promotes the growth of cytotrophoblasts by the paracrine mechanism," Journal of Biochemistry, vol. 117, no. 3, pp. 671-676, 1995.

[85] J. A. Irving and P. K. Lala, "Functional role of cell surface integrins on human trophoblast cell migration: regulation by TGF- $\beta$, IGF-II, and IGFBP-1," Experimental Cell Research, vol. 217, no. 2, pp. 419-427, 1995.

[86] V. K. Han, N. Bassett, J. Walton, and J. R. Challis, "The expression of insulin-like growth factor (IGF) and IGFbinding protein (IGFBP) genes in the human placenta and membranes: evidence for IGF-IGFBP interactions at the feto-maternal interface," The Journal of Clinical Endocrinology and Metabolism, vol. 81, no. 7, pp. 2680-2693, 1996.

[87] T. McKinnon, C. Chakraborty, L. M. Gleeson, P. Chidiac, and P. K. Lala, "Stimulation of human extravillous trophoblast migration by IGF-II is mediated by IGF type 2 receptor involving inhibitory $\mathrm{G}$ protein(s) and phosphorylation of MAPK," The Journal of Clinical Endocrinology and Metabolism, vol. 86, no. 8, pp. 3665-3674, 2001.
[88] P. Bischof and A. Campana, "Molecular mediators of implantation," Best Practice \& Research Clinical Obstetrics \& Gynaecology, vol. 14, no. 5, pp. 801-814, 2000.

[89] P. Viganò, S. Mangioni, F. Pompei, and I. Chiodo, "Maternalconceptus cross talk - a review," Placenta, vol. 24, pp. S56S61, 2003.

[90] A. Meisser, D. Chardonnens, A. Campana, and P. Bischof, "Effects of tumour necrosis factor- $\alpha$, interleukin-1 $\alpha$, macrophage colony stimulating factor and transforming growth factor $\beta$ on trophoblastic matrix metalloproteinases," Molecular Human Reproduction, vol. 5, no. 3, pp. 252-260, 1999.

[91] A. Meisser, P. Cameo, D. Islami, A. Campana, and P. Bischof, "Effects of interleukin-6 (IL-6) on cytotrophoblastic cells," Molecular Human Reproduction, vol. 5, no. 11, pp. 10551058, 1999.

[92] C. L. Librach, S. L. Feigenbaum, K. E. Bass et al., "Interleukin$1 \beta$ regulates human cytotrophoblast metalloproteinase activity and invasion in vitro," The Journal of Biological Chemistry, vol. 269, no. 25, pp. 17125-17131, 1994.

[93] C. Simon, A. Frances, G. Piquette, M. Hendrickson, A. Milki, and M. L. Polan, "Interleukin-1 system in the maternotrophoblast unit in human implantation: immunohistochemical evidence for autocrine/paracrine function," The Journal of Clinical Endocrinology and Metabolism, vol. 78, no. 4, pp. 847-854, 1994.

[94] N. Prutsch, V. Fock, P. Haslinger et al., "The role of interleukin- $1 \beta$ in human trophoblast motility," Placenta, vol. 33, no. 9, pp. 696-703, 2012.

[95] H. Husslein, S. Haider, G. Meinhardt, J. Prast, S. Sonderegger, and M. Knofler, "Expression, regulation and functional characterization of matrix metalloproteinase- 3 of human trophoblast," Placenta, vol. 30, no. 3, pp. 284-291, 2009.

[96] E. Jauniaux, B. Gulbis, L. Schandene, J. Collette, and J. Hustin, "Distribution of interleukin-6 in maternal and embryonic tissues during the first trimester," Molecular Human Reproduction, vol. 2, no. 4, pp. 239-243, 1996.

[97] C. Das, V. S. Kumar, S. Gupta, and S. Kumar, "Network of cytokines, integrins and hormones in human trophoblast cells," Journal of Reproductive Immunology, vol. 53, no. 1-2, pp. 257-268, 2002.

[98] S. Tabibzadeh, Q. F. Kong, A. Babaknia, and L. T. May, "Progressive rise in the expression of interleukin-6 in human endometrium during menstrual cycle is initiated during the implantation window," Human Reproduction, vol. 10, no. 10, pp. 2793-2799, 1995.

[99] D. T. Vandermolen and Y. Gu, "Human endometrial interleukin-6 (IL-6): in vivo messenger ribonucleic acid expression, in vitro protein production, and stimulation thereof by IL-1 beta," Fertility and Sterility, vol. 66, no. 5, pp. 741-747, 1996.

[100] P. Bischof, A. Meisser, and A. Campana, "Involvement of Trophoblast in Embryo Implantation: Regulation by Paracrine factors," Journal of Reproductive Immunology, vol. 39, no. 1-2, pp. 167-177, 1998.

[101] M. Jovanovic and L. Vicovac, "Interleukin-6 stimulates cell migration, invasion and integrin expression in HTR-8/SVneo cell line," Placenta, vol. 30, no. 4, pp. 320-328, 2009.

[102] L. G. de Oliveira, G. E. Lash, C. Murray-Dunning et al., "Role of interleukin 8 in uterine natural killer cell regulation of extravillous trophoblast cell invasion," Placenta, vol. 31, no. 7, pp. 595-601, 2010. 
[103] M. Jovanovic, I. Stefanoska, L. Radojcic, and L. Vicovac, "Interleukin-8 (CXCL8) stimulates trophoblast cell migration and invasion by increasing levels of matrix metalloproteinase (MMP) 2 and MMP9 and integrins $\alpha 5$ and $\beta 1$," Reproduction, vol. 139, no. 4, pp. 789-798, 2010.

[104] B. Toth, T. Haufe, C. Scholz et al., "Placental interleukin-15 expression in recurrent miscarriage," American Journal of Reproductive Immunology, vol. 64, no. 6, pp. 402-410, 2010.

[105] M. Zygmunt, D. Hahn, N. Kiesenbauer, K. Munstedt, and U. Lang, "Invasion of cytotrophoblastic (JEG-3) cells is upregulated by interleukin-15 in vitro," American Journal of Reproductive Immunology, vol. 40, no. 5, pp. 326-331, 1998.

[106] F. Dominguez, S. Martinez, A. Quinonero et al., "CXCL10 and IL-6 induce chemotaxis in human trophoblast cell lines," Molecular Human Reproduction, vol. 14, no. 7, pp. 423-430, 2008.

[107] H. Y. Sela, D. S. Goldman-Wohl, R. Haimov-Kochman et al., "Human trophectoderm apposition is regulated by interferon $\gamma$-induced protein 10 (IP-10) during early implantation," Placenta, vol. 34, no. 3, pp. 222-230, 2013.

[108] K. Nagaoka, H. Nojima, F. Watanabe et al., "Regulation of blastocyst migration, apposition, and initial adhesion by a chemokine, interferon gamma-inducible protein $10 \mathrm{kDa}$ (IP-10), during early gestation," The Journal of Biological Chemistry, vol. 278, no. 31, pp. 29048-29056, 2003.

[109] E. B. Cullinan, S. J. Abbondanzo, P. S. Anderson, J. W. Pollard, B. A. Lessey, and C. L. Stewart, "Leukemia inhibitory factor (LIF) and LIF receptor expression in human endometrium suggests a potential autocrine/paracrine function in regulating embryo implantation," Proceedings of the National Academy of Sciences of the United States of America, vol. 93, no. 7, pp. 3115-3120, 1996.

[110] Z. Kondera-Anasz, J. Sikora, and A. Mielczarek-Palacz, "Leukemia inhibitory factor: an important regulator of endometrial function," American Journal of Reproductive Immunology, vol. 52, no. 2, pp. 97-105, 2004.

[111] H. Bhatt, L. J. Brunet, and C. L. Stewart, "Uterine expression of leukemia inhibitory factor coincides with the onset of blastocyst implantation," Proceedings of the National Academy of Sciences of the United States of America, vol. 88, no. 24, pp. 11408-11412, 1991.

[112] A. M. Sharkey, A. King, D. E. Clark et al., "Localization of leukemia inhibitory factor and Its receptor in human placenta throughout pregnancy," Biology of Reproduction, vol. 60, no. 2, pp. 355-364, 1999.

[113] P. Bischof, L. Haenggeli, and A. Campana, "Effect of leukemia inhibitory factor on human cytotrophoblast differentiation along the invasive pathway," American Journal of Reproductive Immunology, vol. 34, no. 4, pp. 225-230, 1995.

[114] A. Tapia, L. A. Salamonsen, U. Manuelpillai, and E. Dimitriadis, "Leukemia inhibitory factor promotes human first trimester extravillous trophoblast adhesion to extracellular matrix and secretion of tissue inhibitor of metalloproteinases-1 and -2," Human Reproduction, vol. 23, no. 8, pp. 1724-1732, 2008.

[115] P. Suman and S. K. Gupta, "STAT3 and ERK1/2 cross-talk in leukaemia inhibitory factor mediated trophoblastic JEG-3 cell invasion and expression of mucin 1 and Fos," American Journal of Reproductive Immunology, vol. 72, no. 1, pp. 65-74, 2014.

[116] U. A. Kayisli, N. G. Mahutte, and A. Arici, "Uterine chemokines in reproductive physiology and pathology," American
Journal of Reproductive Immunology, vol. 47, no. 4, pp. 213-221, 2002.

[117] H. Fujiwara, T. Higuchi, Y. Sato et al., "Regulation of human extravillous trophoblast function by membrane-bound peptidases," Biochimica et Biophysica Acta, vol. 1751, no. 1, pp. 26-32, 2005.

[118] T. L. Thirkill, K. Lowe, H. Vedagiri, T. N. Blankenship, A. I. Barakat, and G. C. Douglas, "Macaque trophoblast migration is regulated by RANTES," Experimental Cell Research, vol. 305, no. 2, pp. 355-364, 2005.

[119] E. Dimitriadis, L. A. Salamonsen, and L. Robb, "Expression of interleukin-11 during the human menstrual cycle: coincidence with stromal cell decidualization and relationship to leukaemia inhibitory factor and prolactin," Molecular Human Reproduction, vol. 6, no. 10, pp. 907-914, 2000.

[120] P. Paiva, L. A. Salamonsen, U. Manuelpillai et al., "Interleukin-11 promotes migration, but not proliferation, of human trophoblast cells, implying a role in placentation," Endocrinology, vol. 148, no. 11, pp. 5566-5572, 2007.

[121] P. Suman, G. Godbole, R. Thakur et al., "AP-1 transcription factors, mucin-type molecules and MMPs regulate the IL11 mediated invasiveness of JEG-3 and HTR-8/SVneo trophoblastic cells," PLoS One, vol. 7, no. 1, article e29745, 2012.

[122] I. Roth and S. J. Fisher, "IL-10 is an autocrine inhibitor of human placental cytotrophoblast MMP-9 production and invasion," Developmental Biology, vol. 205, no. 1, pp. 194204, 1999.

[123] S. Bauer, J. Pollheimer, J. Hartmann, P. Husslein, J. D. Aplin, and M. Knofler, "Tumor necrosis factor- $\alpha$ inhibits trophoblast migration through elevation of plasminogen activator inhibitor-1 in first-trimester villous explant cultures," The Journal of Clinical Endocrinology and Metabolism, vol. 89, no. 2, pp. 812-822, 2004.

[124] M. Bilban, N. Ghaffari-Tabrizi, E. Hintermann et al., "Kisspeptin-10, a KiSS-1/metastin-derived decapeptide, is a physiological invasion inhibitor of primary human trophoblasts," Journal of Cell Science, vol. 117, no. 8, pp. 13191328, 2004.

[125] P. K. Lala and C. H. Graham, "Mechanisms of trophoblast invasiveness and their control: the role of proteases and protease inhibitors," Cancer Metastasis Reviews, vol. 9, no. 4, pp. 369-379, 1990.

[126] G. E. Lash, H. A. Otun, B. A. Innes et al., "Interferon- $\gamma$ inhibits extravillous trophoblast cell invasion by a mechanism that involves both changes in apoptosis and protease levels," The FASEB Journal, vol. 20, no. 14, pp. 2512-2518, 2006.

[127] J. Pollheimer, P. Husslein, and M. Knofler, "Invasive trophoblasts generate regulatory collagen XVIII cleavage products," Placenta, vol. 26, pp. S42-S45, 2005.

[128] C. H. Graham, I. Connelly, J. R. MacDougall, R. S. Kerbel, W. G. Stetler-Stevenson, and P. K. Lala, "Resistance of malignant trophoblast cells to both the anti-proliferative and anti-invasive effects of transforming growth factor- $\beta$," Experimental Cell Research, vol. 214, no. 1, pp. 93-99, 1994.

[129] G. E. Lash, H. A. Otun, B. A. Innes, J. N. Bulmer, R. F. Searle, and S. C. Robson, "Inhibition of trophoblast cell invasion by TGFB1, 2, and 3 is associated with a decrease in active proteases1," Biology of Reproduction, vol. 73, no. 2, pp. 374381, 2005. 
[130] S. Saito, K. Nishikawa, T. Morii et al., "Cytokine production by CD16-CD56 ${ }^{\text {bright }}$ natural killer cells in the human early pregnancy decidua," International Immunology, vol. 5, no. 5, pp. 559-563, 1993.

[131] S. Haider and M. Knofler, "Human tumour necrosis factor: physiological and pathological roles in placenta and endometrium," Placenta, vol. 30, no. 2, pp. 111-123, 2009.

[132] L. Nadeem, S. Munir, G. Fu et al., "Nodal signals through activin receptor-like kinase 7 to inhibit trophoblast migration and invasion: implication in the pathogenesis of preeclampsia," The American Journal of Pathology, vol. 178, no. 3, pp. 1177-1189, 2011.

[133] A. Athanassiades, G. S. Hamilton, and P. K. Lala, "Vascular endothelial growth factor stimulates proliferation but not migration or invasiveness in human extravillous trophoblast1," Biology of Reproduction, vol. 59, no. 3, pp. 643-654, 1998.

[134] H. Liu, Y. Wu, F. Qiao, and X. Gong, "Effect of leptin on cytotrophoblast proliferation and invasion," Journal of Huazhong University of Science and Technology. Medical Sciences, vol. 29, no. 5, pp. 631-636, 2009.

[135] R. R. Gonzalez, L. Devoto, A. Campana, and P. Bischof, "Effects of leptin, interleukin-1alpha, interleukin-6, and transforming growth factor- $\beta$ on markers of trophoblast invasive phenotype: integrins and metalloproteinases," Endocrine, vol. 15, no. 2, pp. 157-164, 2001.

[136] M. Castellucci, R. de Matteis, A. Meisser et al., "Leptin modulates extracellular matrix molecules and metalloproteinases: possible implications for trophoblast invasion," Molecular Human Reproduction, vol. 6, no. 10, pp. 951958, 2000.

[137] M. R. Junttila, S. P. Li, and J. Westermarck, "Phosphatasemediated crosstalk between MAPK signaling pathways in the regulation of cell survival," The FASEB Journal, vol. 22, no. 4, pp. 954-965, 2008.

[138] G. Daoud, M. Amyot, E. Rassart, A. Masse, L. Simoneau, and J. Lafond, "ERK1/2 and p38 regulate trophoblasts differentiation in human term placenta," The Journal of Physiology, vol. 566, no. 2, pp. 409-423, 2005.

[139] M. Aouadi, B. Binetruy, L. Caron, Y. Le Marchand-Brustel, and F. Bost, "Role of MAPKs in development and differentiation: lessons from knockout mice," Biochimie, vol. 88, no. 9, pp. 1091-1098, 2006.

[140] K. C. Moon, J. S. Park, E. R. Norwitz et al., "Expression of extracellular signal-regulated kinase1/2 and p38 mitogenactivated protein kinase in the invasive trophoblasts at the human placental bed," Placenta, vol. 29, no. 5, pp. 391-395, 2008.

[141] L. R. Coulthard, D. E. White, D. L. Jones, M. F. McDermott, and S. A. Burchill, "p $38^{\mathrm{MAPK}}$ : stress responses from molecular mechanisms to therapeutics," Trends in Molecular Medicine, vol. 15, no. 8, pp. 369-379, 2009.

[142] K. Ono and J. Han, "The p38 signal transduction pathway: activation and function," Cellular Signalling, vol. 12, no. 1, pp. 1-13, 2000.

[143] J. S. Mudgett, J. Ding, L. Guh-Siesel et al., "Essential role for p38 $\alpha$ mitogen-activated protein kinase in placental angiogenesis," Proceedings of the National Academy of Sciences of the United States of America, vol. 97, no. 19, pp. 10454-10459, 2000.

[144] Y. Zhang, F. Jin, X. C. Li et al., "The YY1-HOTAIR-MMP2 signaling axis controls trophoblast invasion at the maternal- fetal interface," Molecular Therapy, vol. 25, no. 10, pp. 2394-2403, 2017.

[145] F. L. Pereira de Sousa, W. Chaiwangyen, D. M. MoralesPrieto et al., "Involvement of STAT1 in proliferation and invasiveness of trophoblastic cells," Reproductive Biology, vol. 17, no. 3, pp. 218-224, 2017.

[146] A. Malik, R. Pal, and S. K. Gupta, "Interdependence of JAKSTAT and MAPK signaling pathways during EGF-mediated HTR-8/SVneo cell invasion," PLoS One, vol. 12, no. 5, article e0178269, 2017.

[147] Z. Huang, S. Li, W. Fan, and Q. Ma, “Transforming growth factor $\beta 1$ promotes invasion of human JEG-3 trophoblast cells via TGF- $\beta /$ Smad3 signaling pathway," Oncotarget, vol. 8, no. 20, pp. 33560-33570, 2017.

[148] Y. Son, Y. K. Cheong, N. H. Kim, H. T. Chung, D. G. Kang, and H. O. Pae, "Mitogen-activated protein kinases and reactive oxygen species: how can ROS activate MAPK pathways," Journal of Signal Transduction, vol. 2011, Article ID 792639, 6 pages, 2011.

[149] B. Halliwell and C. E. Cross, "Oxygen-derived species: their relation to human disease and environmental stress," Environmental Health Perspectives, vol. 102, pp. 5-12, 1994.

[150] J. P. Kehrer, “The Haber-Weiss reaction and mechanisms of toxicity," Toxicology, vol. 149, no. 1, pp. 43-50, 2000.

[151] J. P. Castro, T. Jung, T. Grune, and H. Almeida, "Actin carbonylation: from cell dysfunction to organism disorder," Journal of Proteomics, vol. 92, pp. 171-180, 2013.

[152] G. J. Burton and E. Jauniaux, "Oxidative stress," Best Practice \& Research. Clinical Obstetrics \& Gynaecology, vol. 25, no. 3, pp. 287-299, 2011.

[153] E. Cadenas and K. J. A. Davies, "Mitochondrial free radical generation, oxidative stress, and aging," Free Radical Biology \& Medicine, vol. 29, no. 3-4, pp. 222-230, 2000.

[154] B. P. Tu and J. S. Weissman, "Oxidative protein folding in eukaryotes: mechanisms and consequences," The Journal of Cell Biology, vol. 164, no. 3, pp. 341-346, 2004.

[155] L. He, T. He, S. Farrar, L. Ji, T. Liu, and X. Ma, “Antioxidants maintain cellular redox homeostasis by elimination of reactive oxygen species," Cellular Physiology and Biochemistry, vol. 44, no. 2, pp. 532-553, 2017.

[156] I. Mirończuk-Chodakowska, A. M. Witkowska, and M. E. Zujko, "Endogenous non-enzymatic antioxidants in the human body," Advances in Medical Sciences, vol. 63, no. 1, pp. 68-78, 2018.

[157] M. Roche, P. Rondeau, N. R. Singh, E. Tarnus, and E. Bourdon, "The antioxidant properties of serum albumin," FEBS Letters, vol. 582, no. 13, pp. 1783-1787, 2008.

[158] J. Zhang, X. Wang, V. Vikash et al., "ROS and ROS-mediated cellular signaling," Oxidative Medicine and Cellular Longevity, vol. 2016, Article ID 4350965, 18 pages, 2016.

[159] H. Sies, C. Berndt, and D. P. Jones, "Oxidative stress," Annual Review of Biochemistry, vol. 86, no. 1, pp. 715-748, 2017.

[160] H. Sies, "Oxidative stress: a concept in redox biology and medicine," Redox Biology, vol. 4, pp. 180-183, 2015.

[161] U. Cornelli, G. Belcaro, M. R. Cesarone, and A. Finco, "Analysis of oxidative stress during the menstrual cycle," Reproductive Biology and Endocrinology, vol. 11, no. 1, p. 74, 2013.

[162] K. Bedard and K. H. Krause, "The NOX family of ROSgenerating NADPH oxidases: physiology and pathophysiology," Physiological Reviews, vol. 87, no. 1, pp. 245-313, 2007. 
[163] J. M. Davis and R. L. Auten, "Maturation of the antioxidant system and the effects on preterm birth," Seminars in Fetal \& Neonatal Medicine, vol. 15, no. 4, pp. 191-195, 2010.

[164] K. Strehlow, S. Rotter, S. Wassmann et al., "Modulation of antioxidant enzyme expression and function by estrogen," Circulation Research, vol. 93, no. 2, pp. 170-177, 2003.

[165] X. Xu, J.-Y. Leng, F. Gao et al., "Differential expression and anti-oxidant function of glutathione peroxidase 3 in mouse uterus during decidualization," FEBS Letters, vol. 588, no. 9, pp. 1580-1589, 2014.

[166] N. Sugino, S. Takiguchi, S. Kashida, A. Karube, Y. Nakamura, and H. Kato, "Superoxide dismutase expression in the human corpus luteum during the menstrual cycle and in early pregnancy," Molecular Human Reproduction, vol. 6, no. 1, pp. 19-25, 2000.

[167] K. H. Al-Gubory, C. Garrel, P. Faure, and N. Sugino, "Roles of antioxidant enzymes in corpus luteum rescue from reactive oxygen species-induced oxidative stress," Reproductive Biomedicine Online, vol. 25, no. 6, pp. 551-560, 2012.

[168] S. Preutthipan, S. H. Chen, J. L. Tilly, K. Kugu, R. R. Lareu, and A. M. Dharmarajan, "Inhibition of nitric oxide synthesis potentiates apoptosis in the rabbit corpus luteum," Reproductive Biomedicine Online, vol. 9, no. 3, pp. 264-270, 2004.

[169] Y. Takagi, T. Nikaido, T. Toki et al., "Levels of oxidative stress and redox-related molecules in the placenta in preeclampsia and fetal growth restriction," Virchows Archiv, vol. 444, no. 1, pp. 49-55, 2004.

[170] A. Agarwal, S. Gupta, L. Sekhon, and R. Shah, "Redox considerations in female reproductive function and assisted reproduction: from molecular mechanisms to health implications," Antioxidants \& Redox Signaling, vol. 10, no. 8, pp. 13751404, 2008.

[171] G. Serviddio, G. Loverro, M. Vicino et al., "Modulation of endometrial redox balance during the menstrual cycle: relation with sex hormones," The Journal of Clinical Endocrinology and Metabolism, vol. 87, no. 6, pp. 2843-2848, 2002.

[172] J. Mier-Cabrera, L. Jimenez-Zamudio, E. Garcia-Latorre, O. Cruz-Orozco, and C. Hernandez-Guerrero, "Quantitative and qualitative peritoneal immune profiles, T-cell apoptosis and oxidative stress-associated characteristics in women with minimal and mild endometriosis," BJOG, vol. 118, no. 1, pp. 6-16, 2011.

[173] M. E. Rahiminejad, A. Moaddab, M. Ganji et al., "Oxidative stress biomarkers in endometrial secretions: a comparison between successful and unsuccessful in vitro fertilization cycles," Journal of Reproductive Immunology, vol. 116, pp. 70-75, 2016.

[174] M. S. Salker, M. Christian, J. H. Steel et al., "Deregulation of the serum- and glucocorticoid-inducible kinase SGK1 in the endometrium causes reproductive failure," Nature Medicine, vol. 17, no. 11, pp. 1509-1513, 2011.

[175] E. M. Erkenbrack, J. D. Maziarz, O. W. Griffith et al., "The mammalian decidual cell evolved from a cellular stress response," PLoS Biology, vol. 16, no. 8, article e2005594, 2018.

[176] A. Ochiai, K. Kuroda, R. Ozaki et al., "Resveratrol inhibits decidualization by accelerating downregulation of the CRABP2-RAR pathway in differentiating human endometrial stromal cells," Cell Death \& Disease, vol. 10, no. 4, p. 276, 2019.

[177] Y. Yang, X. Pei, Y. Jin, Y. Wang, and C. Zhang, “The roles of endoplasmic reticulum stress response in female mammalian reproduction," Cell and Tissue Research, vol. 363, no. 3, pp. 589-597, 2016.

[178] X. W. Gu, J. Q. Yan, H. T. Dou et al., "Endoplasmic reticulum stress in mouse decidua during early pregnancy," Molecular and Cellular Endocrinology, vol. 434, pp. 48-56, 2016.

[179] H. J. Gao, Y. M. Zhu, W. H. He et al., "Endoplasmic reticulum stress induced by oxidative stress in decidual cells: a possible mechanism of early pregnancy loss," Molecular Biology Reports, vol. 39, no. 9, pp. 9179-9186, 2012.

[180] M. Christian, Y. Pohnke, R. Kempf, B. Gellersen, and J. J. Brosens, "Functional association of PR and CCAA T/enhancer-binding protein beta isoforms: promoterdependent cooperation between PR-B and liver-enriched inhibitory protein, or liver-enriched activatory protein and PR-A in human endometrial stromal cells," Molecular Endocrinology, vol. 16, no. 1, pp. 141-154, 2002.

[181] M. Christian, X. Zhang, T. Schneider-Merck et al., "Cyclic AMP-induced forkhead transcription factor, FKHR, cooperates with CCAAT/enhancer-binding protein beta in differentiating human endometrial stromal cells," The Journal of Biological Chemistry, vol. 277, no. 23, pp. 20825-20832, 2002.

[182] M. Takano, Z. Lu, T. Goto et al., "Transcriptional cross talk between the forkhead transcription factor forkhead box $\mathrm{O} 1 \mathrm{~A}$ and the progesterone receptor coordinates cell cycle regulation and differentiation in human endometrial stromal cells," Molecular Endocrinology, vol. 21, no. 10, pp. 23342349, 2007.

[183] N. Sugino, K. Shimamura, S. Takiguchi et al., "Changes in activity of superoxide dismutase in the human endometrium throughout the menstrual cycle and in early pregnancy," Human Reproduction, vol. 11, no. 5, pp. 1073-1078, 1996.

[184] N. Sugino, S. Kashida, S. Takiguchi, Y. Nakamura, and H. Kato, "Induction of superoxide dismutase by decidualization in human endometrial stromal cells," Molecular Human Reproduction, vol. 6, no. 2, pp. 178-184, 2000.

[185] C. Yang, W. Lim, F. W. Bazer, and G. Song, "Decanoic acid suppresses proliferation and invasiveness of human trophoblast cells by disrupting mitochondrial function," Toxicology and Applied Pharmacology, vol. 339, pp. 121-132, 2018.

[186] J. Y. Na, J. Seok, S. Park, J. S. Kim, and G. J. Kim, "Effects of selenium on the survival and invasion of trophoblasts," Clinical and Experimental Reproductive Medicine, vol. 45, no. 1, pp. 10-16, 2018.

[187] Y. Zheng, Y. Zhao, Q. Luo et al., "Edaravone protects against cobalt chloride-induced dysfunctions in apoptosis and invasion in trophoblast cells," Molecular Reproduction and Development, vol. 83, no. 7, pp. 576-587, 2016.

[188] J. Kim, K. S. Lee, J. H. Kim et al., "Aspirin prevents TNF$\alpha$-induced endothelial cell dysfunction by regulating the NF- $\kappa$ B-dependent miR-155/eNOS pathway: role of a miR155/eNOS axis in preeclampsia," Free Radical Biology \& Medicine, vol. 104, pp. 185-198, 2017.

[189] V. J. Ebegboni, J. M. Dickenson, and S. D. Sivasubramaniam, "Antioxidative effects of flavonoids and their metabolites against hypoxia/reoxygenation-induced oxidative stress in a human first trimester trophoblast cell line," Food Chemistry, vol. 272, pp. 117-125, 2019.

[190] I. Hassan, A. M. Kumar, H. R. Park, L. H. Lash, and R. LochCaruso, "Reactive oxygen stimulation of interleukin- 6 release in the human trophoblast cell line HTR-8/SVneo by the trichlorethylene metabolite S-(1,2-dichloro)-1-cysteine," Biology of Reproduction, vol. 95, no. 3, p. 66, 2016. 
[191] P. Banerjee, A. Malik, S. S. Malhotra, and S. K. Gupta, "Role of STAT signaling and autocrine action of chemokines during $\mathrm{H}_{2} \mathrm{O}_{2}$ induced HTR-8/SVneo trophoblastic cells invasion," Journal of Cellular Physiology, vol. 234, no. 2, pp. 1380-1397, 2019.

[192] B. Zhuang, X. Luo, H. Rao et al., "Oxidative stress-induced $\mathrm{C} / \mathrm{EBP} \beta$ inhibits $\beta$-catenin signaling molecule involving in the pathology of preeclampsia," Placenta, vol. 36, no. 8, pp. 839-846, 2015.

[193] W. Wang, R. Wang, Q. Zhang, G. Mor, and H. Zhang, "Benzo(a)pyren-7,8-dihydrodiol-9,10-epoxide induces human trophoblast swan 71 cell dysfunctions due to cell apoptosis through disorder of mitochondrial fission/fusion," Environmental Pollution, vol. 233, pp. 820-832, 2018.

[194] M. Murata, K. Fukushima, T. Takao, H. Seki, S. Takeda, and N. Wake, "Oxidative stress produced by xanthine oxidase induces apoptosis in human extravillous trophoblast cells," The Journal of Reproduction and Development, vol. 59, no. 1, pp. 7-13, 2013.

[195] M. C. Velarde and R. Menon, "Positive and negative effects of cellular senescence during female reproductive aging and pregnancy," The Journal of Endocrinology, vol. 230, no. 2, pp. R59-R76, 2016.

[196] Y. Hirota, J. Cha, M. Yoshie, T. Daikoku, and S. K. Dey, "Heightened uterine mammalian target of rapamycin complex 1 (mTORC1) signaling provokes preterm birth in mice," Proceedings of the National Academy of Sciences of the United States of America, vol. 108, no. 44, pp. 1807318078, 2011.

[197] K. E. Burnum, Y. Hirota, E. S. Baker et al., "Uterine deletion of Trp53 compromises antioxidant responses in the mouse decidua," Endocrinology, vol. 153, no. 9, pp. 45684579, 2012.

[198] D. A. Gibson, I. Simitsidellis, O. Kelepouri, H. O. D. Critchley, and P. T. K. Saunders, "Dehydroepiandrosterone enhances decidualization in women of advanced reproductive age," Fertility and Sterility, vol. 109, no. 4, pp. 728734.e2, 2018.

[199] A. Qin, J. Qin, Y. Jin et al., "DHEA improves the antioxidant capacity of endometrial stromal cells and improves endometrium receptivity via androgen receptor," European Journal of Obstetrics, Gynecology, and Reproductive Biology, vol. 198, pp. 120-126, 2016.

[200] Ö. Çelik, M. Acet, A. İmren et al., "DHEA supplementation improves endometrial HOXA-10 mRNA expression in poor responders," Journal of the Turkish-German Gynecological Association, vol. 18, no. 4, pp. 160-166, 2017.

[201] T. A. Coll, G. Chaufan, L. G. Pérez-Tito, M. R. Ventureira, M. d. C. Ríos de Molina, and E. Cebral, "Cellular and molecular oxidative stress-related effects in uterine myometrial and trophoblast-decidual tissues after perigestational alcohol intake up to early mouse organogenesis," Molecular and Cellular Biochemistry, vol. 440, no. 1-2, pp. 89-104, 2018.

[202] J. E. Hodge, "Dehydrated foods, chemistry of browning reactions in model systems," Journal of Agricultural and Food Chemistry, vol. 1, no. 15, pp. 928-943, 1953.

[203] N. Ahmed, "Advanced glycation endproducts-role in pathology of diabetic complications," Diabetes Research and Clinical Practice, vol. 67, no. 1, pp. 3-21, 2005.

[204] R. G. Paul and A. J. Bailey, "Glycation of collagen: the basis of Its central role in the late complications of ageing and diabe- tes," The International Journal of Biochemistry \& Cell Biology, vol. 28, no. 12, pp. 1297-1310, 1996.

[205] S. Del Turco and G. Basta, "An update on advanced glycation endproducts and atherosclerosis," BioFactors, vol. 38, no. 4, pp. 266-274, 2012.

[206] J. Uribarri and K. R. Tuttle, "Advanced glycation end products and nephrotoxicity of high-protein diets," Clinical Journal of the American Society of Nephrology, vol. 1, no. 6, pp. 1293-1299, 2006.

[207] S. R. Thorpe and J. W. Baynes, "Maillard reaction products in tissue proteins: new products and new perspectives," Amino Acids, vol. 25, no. 3-4, pp. 275-281, 2003.

[208] C. Ott, K. Jacobs, E. Haucke, A. Navarrete Santos, T. Grune, and A. Simm, "Role of advanced glycation end products in cellular signaling," Redox Biology, vol. 2, pp. 411-429, 2014.

[209] J. Xie, J. D. Mendez, V. Mendez-Valenzuela, and M. M. Aguilar-Hernandez, "Cellular signalling of the receptor for advanced glycation end products (RAGE)," Cellular Signalling, vol. 25, no. 11, pp. 2185-2197, 2013.

[210] A. Cerami, "Aging of Proteins and Nucleic Acids: What Is the Role of Glucose?," Trends in Biochemical Sciences, vol. 11, no. 8, pp. 311-314, 1986.

[211] J. Uribarri, M. D. del Castillo, M. P. de la Maza et al., "Dietary advanced glycation end products and their role in health and disease," Advances in Nutrition, vol. 6, no. 4, pp. 461-473, 2015.

[212] S. Ruhs, N. Nass, B. Bartling et al., "Preconditioning with Maillard reaction products improves antioxidant defence leading to increased stress tolerance in cardiac cells," Experimental Gerontology, vol. 45, no. 10, pp. 752-762, 2010.

[213] B. Leuner, S. Ruhs, H. J. Brömme et al., "RAGE-dependent activation of gene expression of superoxide dismutase and vanins by AGE-rich extracts in mice cardiac tissue and murine cardiac fibroblasts," Food \& Function, vol. 3, no. 10, pp. 1091-1098, 2012.

[214] A. Simm, S. Ruhs, N. Nass et al., "Physiological and Pathophysiological Importance of Advanced Glycation End-products," Free Radical Biology and Medicine, vol. 65, p. S11, 2013.

[215] S. Ruhs, N. Nass, V. Somoza et al., "Maillard reaction products enriched food extract reduce the expression of myofibroblast phenotype markers," Molecular Nutrition \& Food Research, vol. 51, no. 4, pp. 488-495, 2007.

[216] M. Baumann, "Role of advanced glycation end products in hypertension and cardiovascular risk: human studies," Journal of the American Society of Hypertension, vol. 6, no. 6, pp. 427-435, 2012.

[217] K. de Leeuw, R. Graaff, R. de Vries et al., “Accumulation of advanced glycation endproducts in patients with systemic lupus erythematosus," Rheumatology, vol. 46, no. 10, pp. 1551-1556, 2007.

[218] L. De Groot, M. D. Posthumus, C. G. M. Kallenberg, and M. Bijl, "Risk factors and early detection of atherosclerosis in rheumatoid arthritis," European Journal of Clinical Investigation, vol. 40, no. 9, pp. 835-842, 2010.

[219] V. Srikanth, A. Maczurek, T. Phan et al., "Advanced glycation endproducts and their receptor RAGE in Alzheimer's disease," Neurobiology of Aging, vol. 32, no. 5, pp. 763-777, 2011. 
[220] A. Taguchi, D. C. Blood, G. del Toro et al., "Blockade of RAGE-amphoterin signalling suppresses tumour growth and metastases," Nature, vol. 405, no. 6784, pp. 354-360, 2000.

[221] A. Rojas, H. Figueroa, and E. Morales, "Fueling inflammation at tumor microenvironment: the role of multiligand/rage axis," Carcinogenesis, vol. 31, no. 3, pp. 334-341, 2010.

[222] E. A. Oliver, C. S. Buhimschi, A. T. Dulay et al., "Activation of the receptor for advanced glycation end products system in women with severe preeclampsia," The Journal of Clinical Endocrinology and Metabolism, vol. 96, no. 3, pp. 689-698, 2011.

[223] I. U. Jiménez, E. Díaz-Díaz, J. S. Castro et al., "Circulating concentrations of advanced glycation end products, Its association with the development of diabetes mellitus," Archives of Medical Research, vol. 48, no. 4, pp. 360-369, 2017.

[224] S. Li and H. Yang, "Relationship between advanced glycation end products and gestational diabetes mellitus," The Journal of Maternal-Fetal \& Neonatal Medicine, vol. 32, no. 17, pp. 2783-2789, 2018.

[225] X. Tang, Q. Qin, X. Xie, and P. He, "Protective effect of sRAGE on fetal development in pregnant rats with gestational diabetes mellitus," Cell Biochemistry and Biophysics, vol. 71, no. 2, pp. 549-556, 2015.

[226] H. Konishi, M. Nakatsuka, C. Chekir et al., "Advanced glycation end products induce secretion of chemokines and apoptosis in human first trimester trophoblasts," Human Reproduction, vol. 19, no. 9, pp. 2156-2162, 2004.

[227] Q. T. Huang, M. Zhang, M. Zhong et al., "Advanced glycation end products as an upstream molecule triggers ROS-induced sFlt-1 production in extravillous trophoblasts: a novel bridge between oxidative stress and preeclampsia," Placenta, vol. 34, no. 12, pp. 1177-1182, 2013.

[228] K. Shirasuna, K. Seno, A. Ohtsu et al., “AGEs and HMGB1 increase inflammatory cytokine production from human placental cells, resulting in an enhancement of monocyte migration," American Journal of Reproductive Immunology, vol. 75, no. 5, pp. 557-568, 2016.

[229] K. Seno, S. Sase, A. Ozeki et al., "Advanced glycation end products regulate interleukin- $1 \beta$ production in human placenta," The Journal of Reproduction and Development, vol. 63, no. 4, pp. 401-408, 2017.

[230] M. Lappas, M. Permezel, and G. E. Rice, “Advanced glycation endproducts mediate pro-inflammatory actions in human gestational tissues via nuclear factor- $\kappa \mathrm{B}$ and extracellular signal-regulated kinase 1/2," The Journal of Endocrinology, vol. 193, no. 2, pp. 269-277, 2007.

[231] L. Jiang, J. Yan, and L. Wu, "Study of the relationship between AGEs and oxidative stress damage to trophoblast cell mitochondria," Ginekologia Polska, vol. 88, no. 7, pp. 372-378, 2017. 


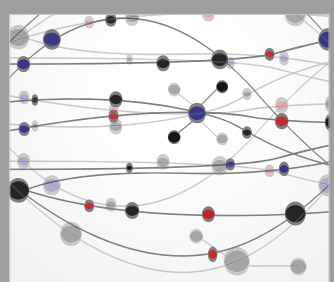

The Scientific World Journal
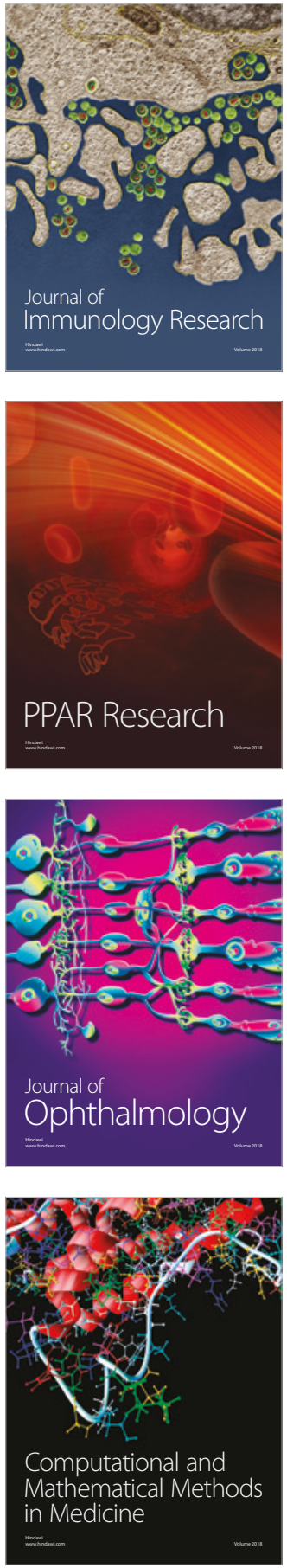

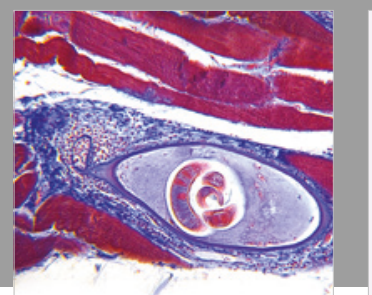

Gastroenterology Research and Practice

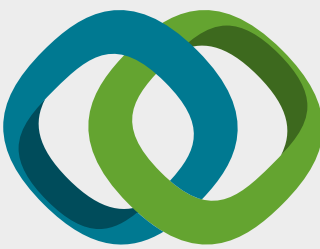

\section{Hindawi}

Submit your manuscripts at

www.hindawi.com
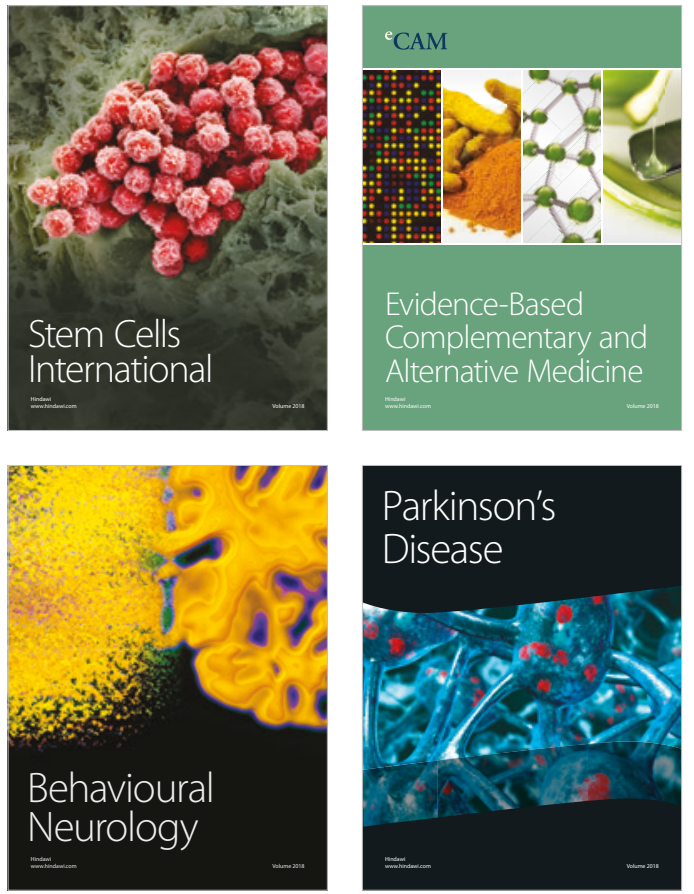

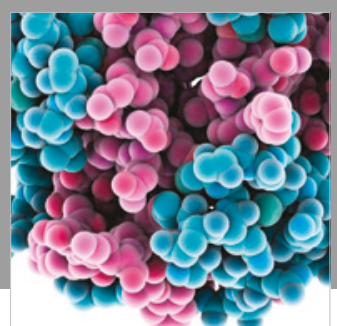

ournal of

Diabetes Research

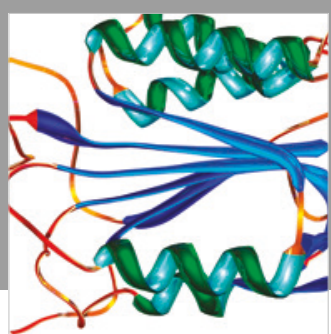

Disease Markers
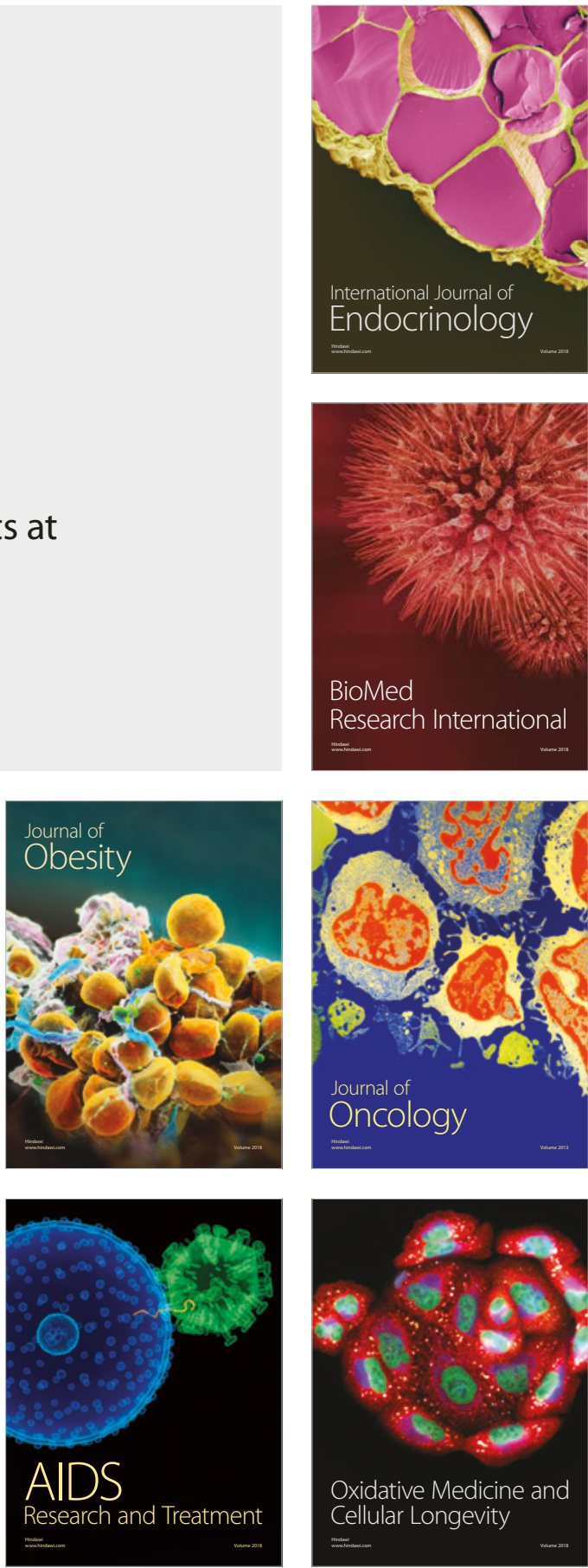